\title{
Percepções dos deputados estaduais sobre o sistema de comissões das Assembleias Estaduais brasileiras
}

\author{
\begin{tabular}{c} 
Marta Mendes da Rocha \\
Programa de Pós-Graduação em Ciências Sociais \\
Universidade Federal de Juiz de Fora \\
Alessandra Costa \\
Centro de Estudos Legislativos \\
Universidade Federal de Minas Gerais \\
\hline \hline
\end{tabular}
}

Resumo: $\mathrm{O}$ artigo confronta a visão da literatura sobre a importância e o papel das comissões permanentes nos legislativos no Brasil e as percepções dos deputados estaduais de 12 estados brasileiros. Busca identificar os pontos de convergência e divergência entre eles e contribuir para ampliar a compreensão sobre o funcionamento e a relevância das comissões parlamentares nas Assembleias Estaduais, assim como os obstáculos à sua atuação. Além disso, o artigo se propõe a identificar e discutir os aspectos e as dimensões enfatizadas pelos deputados e não considerados pela literatura sobre o tema.

Palavras-chave: Poder Legislativo; Assembleias Estaduais; Representação; Comissões parlamentares

Abstract: The purpose of this article is to discuss the view of literature on the importance and the role of Standing Committees in legislatures in Brazil and to contrast it with the perceptions of state representatives from twelve state assemblies. We attempted to identify points of convergence and divergence between that the literature says and, on the other hand, the perceptions of the representatives in order to contribute to further the understanding about the operation and the importance of Standing Committees in the State Assemblies as well as the obstacles to their participation in the legislative process. Furthermore, the article aims to identify and discuss the aspects and dimensions highlighted by the legislators and not considered in the literature.

Keywords: Legislative Branch; State Assemblies; Representation; Standing Committees

OPINIÃO PÚBLICA, Campinas, vol. 18, n², novembro, 2012, p. 278-308 
ROCHA, M. M.; COSTA, A. Percepções dos deputados estaduais sobre o sistema...

Introdução

Os estudos sobre o sistema de comissões no Brasil, com foco em nível nacional, têm apontado um padrão bastante diferente do observado na House norte-americana, onde as comissões revelam-se centrais no processo legislativo. Aspectos como a centralização decisória em torno do Executivo e das lideranças partidárias, a alta rotatividade de membros nas comissões e o frágil poder institucional dessas instâncias configuram um cenário de atuação legislativa limitada das comissões.

Este artigo tem por objetivo observar se esses achados em nível nacional podem ser replicados na arena subnacional, por meio de uma análise da percepção dos deputados estaduais sobre o tema. Para tanto, são utilizados os dados produzidos pela pesquisa "Trajetórias, perfis e padrões de interação de legisladores estaduais em doze unidades da federação", realizada pelo Centro de Estudos Legislativos da Universidade Federal de Minas Gerais (UFMG). Busca-se compreender se, e em que medida, as percepções dos parlamentares coadunam-se com as conclusões da literatura sobre o funcionamento e o desempenho das comissões, bem como a importância atribuída a essa instância pelos deputados.

$\mathrm{O}$ artigo está dividido em quatro seções. A primeira traz uma discussão sobre a literatura pertinente ao tema, especialmente àquela dedicada ao estudo da origem das comissões e sua importância como instâncias decisórias no processo legislativo; na segunda seção, o foco recai sobre as teorias positivas desenvolvidas no âmbito da organização comissional do legislativo norte-americano e sua aplicabilidade nas análises relativas ao funcionamento das comissões permanentes na Câmara dos Deputados, referência importante para se abordar o tema nas Assembleias Estaduais; a terceira seção confronta os argumentos da literatura com as percepções dos deputados estaduais brasileiros das Assembleias investigadas; a quarta e última seção traz as considerações finais.

\section{Comissões parlamentares: origem e funcionamento}

As comissões parlamentares, quando de seu surgimento, eram órgãos criados eventualmente e compostos por um número reduzido de membros do parlamento. Segundo Montero e López (2002), a divisão do trabalho legislativo em órgãos menores como as comissões datam do século XVII, no contexto da Revolução Inglesa. Sua finalidade era obter informação sobre algum assunto concernente aos trabalhos legislativos e permitir maior controle sobre o governo. A criação das comissões como órgãos permanentes e a prática de submeter os projetos às comissões antes de ir ao plenário foi instituída apenas em meados do século XIX, nos Estados Unidos. Entretanto, a atribuição às comissões de importantes prerrogativas no processo legislativo ocorreu apenas em meados do século XX (POLSBY, 1968).

Nos dias atuais, as comissões parlamentares são um dos elementos institucionais mais comuns aos parlamentos. A maioria das legislaturas nacionais está organizada em torno de comissões, mas a estrutura do sistema, suas funções e importância variam de país para país (MONTERO e LOPEZ, 2002). As comissões parlamentares podem ser definidas como "grupos de trabalho, temporários ou permanentes, estruturados a partir de áreas temáticas e constituídos por uma parte dos integrantes de uma assembleia, ao qual esta delega parte de suas funções com o fim de promover maior eficiência e desempenho nos assuntos próprios à função legislativa" (MONTERO e LOPEZ, 2002, p.5; tradução nossa). 
OPINIÃO PÚBLICA, Campinas, vol. 18, n², novembro, 2012, p. 278-308

Em geral, a elas cabe iniciar, analisar, estudar e transformar legislação, além de fiscalizar a implementação das políticas públicas.

Parece haver certo consenso de que a divisão do trabalho legislativo em comissões foi uma resposta à necessidade de dotar de maior funcionalidade e dinamismo os trabalhos legislativos que, em princípio concentrados em um único órgão, mostravam-se lentos e superficiais. Nesse sentido, o surgimento das comissões seria uma forma de reduzir a incerteza em torno da relação entre as políticas e seus resultados e, desse modo, ampliar a qualidade da legislação (KREHBIEL, 1991).

A ampliação do volume de trabalho dos Legislativos, assim como o aumento da complexidade e da incerteza no ambiente sobre os quais as legislaturas operam, também parece ter sido um fator que impulsionou a divisão do trabalho nos parlamentos. Segundo Krehbiel, a maioria, se não todos os estudos históricos, concordam que o surgimento das comissões refletiu essas mudanças que passaram a exigir das legislaturas respostas complexas em termos de regulação e de políticas públicas (KREHBIEL, 1991).

Esse ponto também é defendido por Polsby (1968). O autor mostra que, durante o século XIX, nos Estados Unidos, havia uma grande resistência em atribuir tarefas importantes às comissões parlamentares, justificada pelo temor de delegar a poucos a responsabilidade por decisões importantes. Apenas a partir de meados do século XX, o sistema de comissões na House americana começou a se desenvolver lentamente até adquirir os contornos que possui hoje. Um fator decisivo, segundo Polsby, foi o aumento no volume das atividades legislativas e a ampliação da incerteza no ambiente político que passaram a exigir dos legisladores a criação de um novo formato para o processo legislativo, capaz de oferecer mais agilidade aos trabalhos.

Também é possível afirmar que o desenvolvimento do sistema de comissões nos moldes do que é praticado hoje ocorreu paralelamente ao fortalecimento do Poder Legislativo, à medida que este deixou de ser um órgão meramente consultivo ou de fiscalização e se tornou uma arena central no que tange à produção legal. Novamente de acordo com Krehbiel (1991), as legislaturas, historicamente, lidam com o problema de obter fontes independentes de informações e expertise. Nesse sentido, a divisão do trabalho com a consequente atribuição de cargos e prerrogativas a grupos menores de parlamentares impactaria não apenas a efetividade com a qual as políticas são concebidas e implementadas, mas, também, a importância da legislatura no processo governamental (KREHBIEL, 1991, p.2). Com o progressivo fortalecimento do Poder Legislativo, as comissões, de órgãos eventuais e temporários, subordinados ao plenário, passaram a ser instâncias de constituição automática no início da legislatura e rota obrigatória dos projetos de lei.

Apesar das inúmeras evidências que associam o surgimento do sistema de comissões ao aumento da incerteza no ambiente e do volume do trabalho legislativo, há autores que entendem a origem da divisão do trabalho no parlamento de outra forma. As teorias distributivistas, embora não neguem o papel informacional desempenhado pelas comissões, veem nelas uma função ainda mais importante: permitir a busca de ganhos de troca pelos parlamentares em bases estáveis contornando, assim, os problemas decorrentes do caráter cíclico da regra majoritária (ARROW, 1963; SHEPSLE e WEINGAST, 1987; WEINGAST e MARSHALL, 1988). 
ROCHA, M. M.; COSTA, A. Percepções dos deputados estaduais sobre o sistema...

A compreensão do funcionamento das comissões parlamentares, porém, vai além da investigação dos fatores que motivaram sua origem. Sabe-se que a criação de instituições é sempre cercada de incertezas e que nem sempre as instituições funcionam segundo as intenções de seus criadores. Não raro, por necessidade de adaptação e sobrevivência, as instituições passam a desempenhar funções não previstas por seus idealizadores e a exercer papéis que não haviam sido antecipados pelos atores políticos (HALL e TAYLOR, 2003). A importância das comissões parlamentares no processo legislativo e as funções cumpridas por elas são temas que têm merecido bastante atenção nos estudos legislativos nos Estados Unidos. Mais recentemente, o tema passou a receber maior atenção de alguns estudiosos do processo legislativo no Brasil (PEREIRA e Mueller, 2000; SANTOS, 2003; RICCI e LEMOS, 2004; SANTOS e ALMEIDA, 2005; NASCIMENTO, 2007). Reconhece-se que o grau de importância das comissões parlamentares no processo legislativo, assim como os papéis desempenhados por elas, variam de contexto para contexto, dependendo de aspectos institucionais e organizacionais do Legislativo. Entre estes aspectos, destacam-se a força dos partidos políticos na arena parlamentar, as prerrogativas controladas pelas comissões e a força do próprio Poder Legislativo frente ao Executivo (MONTERO e LÓPEZ, 2002).

\section{Comisssões parlamentares: o que diz a literatura}

Os legislativos brasileiros também organizam seu trabalho no formato de comissões. Na Câmara dos Deputados, no Senado Federal e em todas as Assembleias Estaduais brasileiras, está previsto o funcionamento de um sistema composto por comissões permanentes que subsistem ao término da legislatura, tendo cotidianamente a função de apreciar os assuntos e as proposições submetidos ao seu exame e sobre eles dar parecer; e por comissões temporárias, que se extinguem ao término da legislatura, quando atingido o fim para que foram criadas ou quando findo o prazo estipulado para seu funcionamento. Entre as comissões temporárias estão as especiais, as de inquérito e a de representação ${ }^{1}$.

Além das atribuições relacionadas à elaboração legislativa, as comissões têm a função regimental de fiscalizar e monitorar permanentemente os atos das autoridades e órgãos públicos. Cabe às comissões, ainda, fazer a mediação entre o Poder Legislativo e a sociedade, por meio, por exemplo, da realização de audiências públicas e do recebimento de petições.

As principais conclusões sobre o papel desempenhado pelas comissões no processo legislativo resultam de estudos sobre a Câmara dos Deputados e sobre o processo legislativo nacional. As teorias positivas de organização legislativa desenvolvidas no contexto dos estudos sobre o Congresso norteamericano são referência dessas análises. Uma das razões para tal deriva de algumas semelhanças entre ambos os sistemas políticos como o presidencialismo, o bicameralismo e a existência de um complexo

\footnotetext{
1 Os Regimentos Internos da Câmara dos Deputados e do Senado Federal preveem a criação de Subcomissões Permanentes, Especiais ou Temporárias, constituídas pelas Comissões Permanentes e sem poder decisório. No caso dos estados, nem todos os regimentos estipulam a criação de subcomissões.
} 
OPINIÃO PÚBLICA, Campinas, vol. 18, n², novembro, 2012, p. 278-308

sistema de comissões permanentes. Como afirmam Pereira e Mueller (2000), essas semelhanças sugerem que as teorias referidas poderiam oferecer caminhos para explicar o funcionamento do Congresso brasileiro. Por outro lado, várias diferenças importantes entre os dois sistemas apontam para limitações daquelas teorias para se entender o processo legislativo no Brasil (PEREIRA e MUELLER, 2000, p. 46).

A seguir, são apresentados os principais aspectos destacados pela literatura para explicar os diferentes papéis desempenhados pelas comissões no processo legislativo. Em seguida, são apresentadas algumas conclusões dos estudiosos do legislativo brasileiro sobre o sistema de comissões na Câmara dos Deputados. O objetivo é destacar as principais dimensões do debate em torno do processo legislativo brasileiro e da atuação das comissões parlamentares para, na seção seguinte, contrastá-las às percepções dos deputados estaduais brasileiros.

\section{Construção de acordos/negociação e estabilização do processo de barganha}

As teorias distributivistas, bastante influentes no contexto norte-americano, sustentam que as comissões são instâncias decisórias cruciais porque permitem a ocorrência, em bases estáveis, de um mercado de votos entre os parlamentares. Algumas premissas desse modelo são a forte conexão eleitoral entre representantes e eleitores concentrados geograficamente, a composição das comissões pelo critério de autosseleção e por membros com preferências extremas em relação à área de política sob jurisdição das comissões, o comportamento paroquialista dos parlamentares que se guiariam predominantemente pelo objetivo de alocar recursos para suas bases eleitorais de modo a assegurar sua reeleição, e a existência de partidos fracos incapazes de constranger as escolhas de seus membros (ShePsle e WeInGASt, 1987; Shepsle, 1986). Dessa forma, sob o olhar distributivista, o sistema de comissões seria o eixo estruturador do processo legislativo porque permitiria "a ocorrência estável das trocas de apoio necessárias à aprovação de políticas distributivistas" tornando críveis os compromissos assumidos pelos legisladores (LIMONGI, 1994, p.9). Na prática, isso significa que as comissões permitem a negociação, a barganha e a realização de acordos por meio dos quais os parlamentares fazem concessões em matérias de menor importância esperando serem recompensados por seus pares em uma próxima rodada do jogo.

\section{Produção de ganhos informacionais e redução da incerteza sobre a relação entre políticas e resultados}

As teorias informacionais de organização legislativa, embora não descartem totalmente o comportamento distributivista, assinalam que os parlamentares, como possuem aversão a riscos, procuram compatibilizar a busca por ganhos de troca e a busca por ganhos de informação. As comissões são vistas, neste modelo, como instâncias para as quais os parlamentares delegam poder em troca da produção de ganhos informacionais que minimizem as incertezas que cercam as decisões. As perdas decorrentes da delegação seriam compensadas pela informação produzida pelas comissões e atenuadas pela composição das mesmas com especialistas de diferentes pontos do espectro político. As comissões seriam heterogêneas e representativas do legislador mediano. A elas caberia, por meio dos diversos recursos disponíveis e pelas oportunidades oferecidas através da interação face-a-face entre seus 
ROCHA, M. M.; COSTA, A. Percepções dos deputados estaduais sobre o sistema...

membros, estudar a fundo as diversas proposições a elas submetidas de modo a subsidiar uma decisão mais informada dos legisladores.

\section{Promoção dos interesses do partido majoritário}

Segundo as teorias partidárias (COX e MCCUBBINS, 1993), mesmo diante de uma estrutura descentralizada, a influência dos líderes partidários sobre o recrutamento de membros para as comissões e sobre o destino e a sobrevivência política dos parlamentares de suas bancadas assegurariam a essas lideranças grande influência sobre o processo legislativo. A organização legislativa daria aos partidos prerrogativas e recursos com os quais eles obteriam cooperação e disciplina junto a seus membros, agindo como estabilizadores do processo decisório. Na prática, as comissões seriam importantes como meios pelos quais o partido majoritário pode articular seus interesses, exercer controle sobre a agenda legislativa e aprovar políticas coerentes com suas preferências (Cox e McCUBBINS, 1993). Estes autores reconhecem o papel central das comissões, mas criticam a ideia de que elas seriam plenamente autônomas e suas decisões invioláveis. Para eles, a centralidade decisória das comissões nos legislativos norte-americanos evidencia não um enfraquecimento dos partidos em detrimento das comissões, mas antes, um complexo processo de delegação de tarefas do partido para as comissões, sem que isto implique, necessariamente em abdicação ou perda de poderes por parte do partido (NASCIMENTO, 2007).

\section{Espaço propício para a atuação de minoras, para a fiscalização e para a atuação das oposições}

Em geral, as comissões permanentes, além de se dedicarem ao estudo das proposições de lei, possuem a função de exercer controle sobre o governo nas áreas de políticas que correspondem à sua atuação. Alguns autores sustentam que a organização descentralizada do parlamento em comissões permanentes pode favorecer a função fiscalizadora do Legislativo ao fornecer subsídios informacionais aos parlamentares acerca das políticas públicas. Além disso, afirma-se que a existência de legislativos descentralizados, bicamerais, com um forte sistema de comissões e com alocação de postos institucionais a partir de regras de proporcionalidade partidária, favoreceria o controle porque permitiria a atores institucionais variados, inclusive às minorias e oposições, a oportunidade de vocalizarem suas preferências (por meio de instrumentos como o voto em separado e o pedido de vistas, por exemplo), acessarem informações relevantes e pôr em andamento ações de controle (STROM, 1990; ANASTASIA e Melo, 2002; RICCI e LEMOS, 2004; LEMOS, 2006)². Segundo Strom (2000), a correspondência entre a jurisdição das comissões e a das pastas ministeriais seria uma forma de potencializar a ação das oposições.

\footnotetext{
${ }^{2}$ As Comissões Parlamentares de Inquérito (CPI) que funcionam em caráter temporário também são instâncias centrais quando o assunto é a fiscalização.
} 
OPINIÃO PÚBLICA, Campinas, vol. 18, no 2, novembro, 2012, p. 278-308

No Brasil, essa dimensão do funcionamento das comissões permanentes não tem recebido muita atenção da literatura. Em se tratando da atividade de controle, os estudos tendem a enfatizar mais as comissões parlamentares de inquérito, de caráter temporário (FIGUEIREDO, 2001; LEMOS, 2006).

\section{Obstáculos à atuação das comissões da Câmara dos Deputados}

A maioria dos estudiosos do Legislativo no Brasil concorda que o processo legislativo, em nível nacional, não pode ser compreendido exclusivamente por qualquer uma das teorias positivas. Figueiredo e Limongi (1999) argumentam neste sentido ao enfatizarem duas diferenças fundamentais entre o sistema norte-americano e o brasileiro: em primeiro lugar, não se vê no sistema político brasileiro o padrão altamente descentralizado que se observa na House norte-americana, onde as comissões constituem-se como elementos centrais no processo legislativo. Segundo, ao contrário dos presidentes norte-americanos, os chefes do Executivo brasileiros contam com uma série de prerrogativas, o que os tornam peças-chaves no processo decisório. A constatação desses traços institucionais é o ponto de partida para o estudo do funcionamento e do desempenho das comissões nos legislativos brasileiros. São apresentados a seguir os principais aspectos destacados pela literatura sobre o tema.

\section{Centralização decisória em torno do Poder Executivo}

Montero e López argumentam que "as legislaturas que desempenham uma função decisiva no processo legislativo, em geral, possuem comissões mais desenvolvidas e ativas, enquanto nas legislaturas mais submetidas ao presidente, em geral, as comissões têm menos poder" (MONTERO e LOPEZ, 2002, p. 8; tradução nossa). Este aspecto remonta, portanto, à forma como estão distribuídas prerrogativas e atribuições entre os Poderes Executivo e Legislativo e se ela resulta em uma dinâmica decisória em que há equilíbrio entre os poderes ou predomínio de um sobre o outro.

Na Ciência Política brasileira, essa dimensão tem sido enfatizada, afirmando-se que os poderes pró-ativos e reativos assegurados ao presidente pela Constituição de 1988, combinados à centralização de prerrogativas em torno das lideranças partidárias, reduzem a atuação dos parlamentares e, mais especificamente, das comissões no processo legislativo (FIGUEIREDO e LIMONGI, 1999; PEREIRA e MUELLER, 2000; SANTOS, 2003) ${ }^{3}$. Além dos poderes de veto total e parcial, os presidentes brasileiros detêm o monopólio de iniciar legislação nas áreas tributária, orçamentária e administrativa, o recurso de solicitar urgência, a possibilidade de emitir medidas provisórias com vigência imediata a partir de sua publicação e de editar leis delegadas, além do direito de impor restrições a emendas orçamentárias e propor emendas constitucionais (SANTOS, 2006; FIGUEIREDO e LIMONGI, 1999; FIGUEIREDO, 2008). O predomínio do Executivo é comprovado por dados que evidenciam o elevado índice de sucesso do presidente na aprovação de suas propostas, sua alta capacidade de influir na agenda e no ritmo do processo decisório,

\footnotetext{
${ }^{3}$ Os recursos e poderes presidenciais incluem, ainda, a prerrogativa de indicar e destituir autoridades do Estado e do Governo, o que garante ao Presidente a capacidade de negociar recursos com os partidos em troca de apoio parlamentar (AmoRIM NETO, 1998; Amorim Neto e SANTOS, 2003).
} 
ROCHA, M. M.; COSTA, A. Percepções dos deputados estaduais sobre o sistema...

de bloquear matérias contrárias aos seus interesses e de predominar nas áreas de políticas com maiores impactos (Figueiredo e Limongl, 1999; Pereira e Mueller, 2000; SANTOS, 2003).

Diante dessa centralização decisória, as comissões desempenhariam um papel apenas secundário no processo de decisão, que tenderia a ser deslocado para o plenário por influências das lideranças partidárias. Pereira e Mueller chegam mesmo a afirmar que "a existência e o funcionamento do sistema de comissões estão subordinados às preferências do Executivo. Ou seja, se as comissões estão prestando algum papel no processo legislativo, este não pode ser contrário aos interesses do Executivo, pois o Executivo tem diversos meios de contornar as comissões, forçá-las a cooperar ou punir seus desvios" (PEREIRA e MUELleR, 2000, p. 46). Entre esses meios, os autores destacam a possibilidade de acelerar a apreciação de proposições de seu interesse e de manipular a composição das comissões, aspectos que serão discutidos a frente.

\section{Centralização decisória no interior do Legislativo}

Segundo vários autores, a centralização decisória não seria apenas resultante dos poderes constitucionais do Executivo. Combinados a estes estariam os direitos e as prerrogativas assegurados às lideranças partidárias. Estes as capacitariam a influenciar a agenda e o ritmo dos trabalhos legislativos, retirando do parlamentar individual e das comissões a possibilidade de exercerem maior protagonismo no processo decisório. No interior da Câmara dos Deputados, são as lideranças partidárias, juntamente com o presidente da casa, que definem a agenda legislativa. Os líderes têm a prerrogativa de indicar e substituir membros das comissões permanentes e mistas (neste último caso, as comissões que analisam o orçamento e as medidas provisórias); retirar matérias das comissões antes do parecer final, por meio do requerimento de urgência, e enviá-las ao Plenário; representar todos os membros do partido no Legislativo e restringir emendas e votações em separado (FIGUEIREDO e LIMONGI, 1999; FIGUEIREDO, 2007; SANTOS, 2003). Predominaria, assim, uma distribuição desigual de poder no interior do parlamento. A ideia implícita aqui é a de que as comissões parlamentares nos legislativos brasileiros não teriam incentivos para se dedicar ao estudo, análise, debate ou à construção de acordos em torno das proposições, pois as decisões estariam sempre subordinadas aos acordos previamente construídos pelas lideranças partidárias, ao poder de agenda e de veto reservado ao presidente da casa ou à decisão final do plenário.

Segundo Figueiredo e Limongi (1999), nem o modelo distributivista nem o modelo informacional seriam adequados para explicar a lógica decisória do Congresso brasileiro. Isso porque são os partidos, através das lideranças partidárias e do Colégio de Líderes, e não as comissões, que estruturam o processo decisório e emprestam estabilidade ao processo de barganha coletiva (FIGUEIREDO e LIMONGI, 1999, p.45).

Enquanto alguns autores destacam os efeitos positivos da composição proporcional dos órgãos no interior do Legislativo, outros mostram que essa regra tende a beneficiar os partidos maiores, que têm um número mais elevado de membros em cada comissão, o que os capacita a eleger os presidentes e vice-presidentes das mesmas. Em verdade, como assinalam Pereira e Mueller (2000), embora, oficialmente, estes postos sejam compostos por meio de eleição com voto secreto e maioria absoluta a cada dois anos, na prática, a decisão envolve boa dose de negociação entre os líderes partidários e a 
OPINIÃO PÚBLICA, Campinas, vol. 18, n², novembro, 2012, p. 278-308

Mesa Diretora. Dessa forma, os maiores partidos que, no caso brasileiro, geralmente fazem parte da base de apoio ao governo, passam a ocupar postos de direção nas comissões mais estratégicas. Devido às importantes atribuições dos presidentes de comissão e dos relatores (indicados pelos presidentes), 0 governo teria um alto controle sobre o processo legislativo nas comissões. Segundo Lemos (2006), essa teria sido a regra nas comissões mais importantes do Senado em toda a década de 1990.

Essa explicação aproxima a dinâmica legislativa brasileira do propalado pelo modelo partidário (Figueiredo e Limongl, 1999; SANTOS, 1997, 2003; Amorim Neto e SANTOS, 2002, 2003; Diniz, 2005). A diferença está em que, no modelo partidário, não se despreza o papel das comissões e estas são vistas como objetos de disputa política justamente devido aos seus poderes institucionais (CoX e MccuBBINS, 1993; NASCIMENTO, 2007).

\section{Prerrogativa do pedido de urgência}

O uso frequente do pedido de urgência (pelo Executivo, para projetos de sua iniciativa, e pelos líderes partidários) é um dos obstáculos mais destacados ao trabalho das comissões. Através dessa prerrogativa, os líderes partidários alteram o fluxo ordinário das matérias podendo, a qualquer momento, retirar as proposições das comissões, mesmo que estas não tenham sido devidamente apreciadas, e transferi-las para a decisão em Plenário. Dessa forma, fica reduzido o tempo disponível para a apreciação, estudo e debate da matéria e para a elaboração dos pareceres (FIGUEIREDO e LIMONGI, 1999: p. 56; Pereira e Mueller, 2000; Santos e Almeida, 2008). O pedido de urgência também reduz a capacidade dos parlamentares de realizarem modificações nas proposições já que, segundo o Regimento Interno da Câmara dos Deputados (RI CD), uma proposta que tramita nesse regime só pode receber emendas da comissão, de um quinto dos membros da Câmara ou dos líderes que representem esse número (Art. 120 RI CD). No Brasil, embora previsto como recurso a ser utilizado extraordinariamente, em matéria de urgência e relevância, o requerimento de urgência tornou-se comum e seu número é expressivo. Seu uso, como destacam vários autores, está bastante associado às altas taxas de aprovação das propostas do Executivo (FIgueiredo e Limongl, 1999; Pereira e Mueller, 2000).

Mais recentemente, alguns estudiosos vêm tentando compreender melhor o uso dessa prerrogativa. Pereira e Mueller (2000), por exemplo, propõem que a decisão de utilizar a urgência depende da pressa do Executivo em ver uma matéria aprovada combinada à distância entre suas preferências e a das comissões. Nesse sentido, as comissões podem vir a desempenhar um papel informacional quando suas preferências não se distanciam muito das do Executivo e este percebe que pode ganhar em deixar as comissões apreciarem o projeto no tempo regular. Uma interpretação alternativa sobre o uso do pedido de urgência pode ser encontrada em Santos e Almeida (2008). Os autores veem uma lógica informacional por trás do comportamento dos líderes, lógica esta que explicaria a forma e o momento em que a urgência é solicitada. Por verem as comissões como importantes para a redução da incerteza e, ao mesmo tempo, temerem que elas distanciem a proposição do ponto ideal preferido pelo Executivo, os líderes governistas optariam por pedir urgência em um momento 
ROCHA, M. M.; COSTA, A. Percepções dos deputados estaduais sobre o sistema...

estratégico: após as comissões já terem iniciado o estudo das matérias, mas antes que elas tenham emitido um parecer ${ }^{4}$.

\section{Alta rotatividade de membros nas comissões}

Outro aspecto enfatizado pelos estudiosos como um obstáculo ao bom funcionamento das comissões permanentes diz respeito à alta rotatividade de membros, seja entre as sessões, seja dentro de uma mesma sessão legislativa. Isso ocorreria devido à prerrogativa dos líderes partidários de indicar e substituir a qualquer momento os membros das comissões e à capacidade do Executivo de manipular as nomeações. Não raro, o Executivo, às vésperas de votações importantes, manipula a composição das comissões favorecendo parlamentares mais leais ao governo ou mais próximos de suas preferências por meio dos líderes governistas (PEREIRA e MUELleR, 2000).

A alta rotatividade de membros nas comissões seria um desincentivo para os parlamentares se especializarem ou para se empenharem na realização de trocas intertemporais de apoio porque os acordos feitos no presente não poderiam ser honrados no futuro e porque o parlamentar não poderia ter segurança de não ser retirado da comissão contra a sua vontade (RICCI e LEMOS, 2004; FIGUEIREDO e LIMONGI, 1999; Pereira e Mueller, 2000). Esse fato seria também uma evidência contrária è tese da composição das comissões por autosseleção, crucial para a teoria distributivista ${ }^{5}$.

\section{Fraco poder institucional das comissões}

Fechando o argumento que sustenta o alto nível de centralização decisória no Brasil e a fragilidade das comissões permanentes, os autores destacam a fraca base institucional destas últimas, evidenciadas pela limitação de suas prerrogativas decisórias. A referência central, neste caso, é o Congresso norte-americano. Shepsle e Weingast (1987) argumentam que a importância das comissões do Congresso norte-americano no processo decisório reside nos gate-keeping power, poder de barrar legislação, e no veto ex-post, autoridade para preservar o status quo inicial frustrando qualquer proposta, mesmo depois de ela ter sido apreciada e modificada pelo plenário. Este último deve-se, principalmente, à sequência do processo e à existência da Comissão de Conferência (Confference Committee) que tem a função de compatibilizar as propostas do Senado e da Câmara (WEINGAST e MARSHALL, 1988).

As comissões brasileiras, por seu turno, não contam com prerrogativas semelhantes. 0 poder das comissões para discutir e votar matéria sem necessidade de apreciação do Plenário (poder conclusivo), previsto na Constituição Federal, no Regimento Interno da Câmara dos Deputados e de algumas Assembleias Estaduais, poderia funcionar como uma espécie de closed rule a favor das

\footnotetext{
${ }^{4}$ As variáveis críticas, segundo os autores, que constrangem a decisão dos líderes em pedir urgência e o momento de fazê-lo seriam: a impaciência dos partidos governistas em obterem retornos eleitorais, a expectativa em relação à quantidade e à qualidade de informação a ser produzida pelas comissões, as preferências do Executivo e as preferências dos membros da comissão (SAntos e AlmEIdA, 2008).

${ }^{5}$ Ricci e Lemos (2004), estudando a composição da Comissão de Agricultura e Política Rural da Câmara, concluem pela alta rotatividade de membros. Entretanto, os atores mostram que a profissão era um critério mais decisivo para explicar a permanência dos parlamentares do que os laços eleitorais na área rural.
} 
OPINIÃO PÚBLICA, Campinas, vol. 18, n², novembro, 2012, p. 278-308

comissões. Entretanto, pelo menos no que se refere à Câmara dos Deputados, os estudos mostram que esta prerrogativa, na verdade, tem tido pouco impacto sobre a produção legal (FIGUEIREDO e LIMONGI, 1999; PeREIRA e MUELLER, 2000). Isso porque o poder conclusivo das comissões se restringe a matérias com pouco impacto sobre a produção legal e ao Plenário é reservada a possibilidade de requerer a apreciação da matéria mediante recurso dos deputados. Dessa forma, uma vez que uma proposta é enviada ao Plenário, ela pode ser alterada distanciando-se da preferência da comissão. Além disso, como afirmam Pereira e Mueller (2000), o uso frequente do pedido de urgência não permite às comissões a opção defensiva de impedir que a proposta vá a Plenário.

\section{Algumas comissões são mais importantes que outras}

Por último, vale a pena considerar um aspecto destacado na literatura que, embora não tenha recebido muita atenção, parece apontar para uma via interessante de análise do funcionamento das comissões. Segundo alguns autores, algumas comissões constituir-se-iam em arenas mais importantes, estratégicas e valorizadas pelos partidos e parlamentares do que outras. Nesse sentido, não seria possível apontar uma única dinâmica de funcionamento para todas as comissões. Este é o argumento de Ribeiral (1998), que afirma que a Comissão de Constituição, Justiça e Redação (CCJ) da Câmara dos Deputados, a despeito das altas taxas de rotatividade, é extremamente produtiva, capaz de incentivar a especialização e de exercer seu poder decisório, configurando-se como um importante veto player. O mesmo é concluído por Lemos (2006) a respeito da Comissão de Constituição, Justiça e Cidadania e a da Comissão de Assuntos Econômicos do Senado Federal que, com base em vários indicadores de desempenho, foram as que se mostraram mais ativas durante a década de $1990^{6}$.

\section{Comissões parlamentares nos legislativos estaduais}

Um esclarecimento importante deve ser feito a respeito do fato de se utilizar conclusões da literatura sobre o processo legislativo nacional para analisarem-se dados produzidos em uma investigação sobre os legislativos estaduais. Os estudos sobre o processo legislativo no nível estadual são ainda pouco numerosos e pode-se dizer que apenas recentemente o processo legislativo estadual e a relação entre Executivo e Legislativo nos estados despontaram como objetos de investigação atraentes para os cientistas políticos brasileiros. Dessa forma, não é possível fazer afirmações seguras, seja sobre o grau de institucionalização, seja sobre o funcionamento e o desempenho do sistema de comissões nas Assembleias Legislativas.

Sabe-se que no Brasil existe uma grande homogeneidade em relação a alguns traços fundamentais do sistema político, presentes tanto em nível nacional como subnacional. Este seria o

\footnotetext{
${ }^{6}$ As conclusões de Lemos (2006) sobre as comissões do Senado Federal diferem um pouco da interpretação dominante, que tende a enfatizar a fragilidade das comissões dos legislativos brasileiros. A autora destaca a alta taxa de aprovação de projetos oriundos de comissão em relação aos iniciados por senadores individuais e a grande importância atribuída pelos senadores a pertencer às comissões. Ainda assim, a autora mostra que a importância e o desempenho variam muito de comissão para comissão (LEMOS, 2006, p. 159).
} 
ROCHA, M. M.; COSTA, A. Percepções dos deputados estaduais sobre o sistema...

caso, principalmente, do presidencialismo, do multipartidarismo e do sistema de representação proporcional, além das regras que regem a produção de políticas públicas, em grande parte, muito similares. No que se refere ao sistema de separação de poderes, o cenário subnacional replica o federal, com a diferença de que, nos estados, os legislativos são unicamerais. Nesse sentido, não seria surpresa se alguns padrões observados no processo político em nível nacional se reproduzissem na política estadual. É possível observar grandes semelhanças entre os poderes constitucionais dos governadores e do presidente, especialmente no que se refere à delegação de prerrogativas legislativas ao Poder Executivo, assim como nas competências do Poder Legislativo (SANTOS, 2001; TOMIO, 2006).

Nos 12 estados investigados neste artigo, os governadores detêm as prerrogativas legislativas de iniciativa de lei ordinária e de emenda constitucional, iniciativa exclusiva na proposição do orçamento e em certas áreas de políticas, prerrogativa de requerer tramitação de urgência para projetos de sua iniciativa e poder de veto total e parcial de projetos de lei. Em 10 estados, admite-se a elaboração de leis delegadas no processo legislativo. Com base nessas semelhanças, alguns autores sugerem que, no nível estadual, a predominância do Executivo na função legislativa seria ainda mais acentuada (ABRúcıo, 1998) e que seria possível observar a mesma divisão de trabalho entre os poderes na qual o Executivo ficaria responsável pelas áreas e políticas de maior impacto (FIGUEIREDO e LIMONGI, 1999; PEREIRA e MUELLER, 2000; Amorim Neto e SANTOS, 2002; TOMı e RiccI, 2008).

Entretanto, também há diferenças importantes a serem consideradas. Nos estados, a prerrogativa do pedido de urgência, apontada como um dos maiores obstáculos ao trabalho das comissões, também está disponível aos governadores. Porém, há restrições ao seu uso nos Regimentos Internos de alguns estados ${ }^{7}$, especialmente no que se refere ao número de proposições que podem tramitar em regime de urgência simultaneamente, em uma mesma sessão legislativa ou em cada Ordem do Dia e quanto às matérias e aos tipos de proposições que podem tramitar neste regime.

A principal diferença, entretanto, consiste na prerrogativa de editar medidas provisórias, prevista na Constituição Federal e largamente utilizada por todos os presidentes desde a redemocratização. Entre os estados investigados neste artigo, esse recurso está disponível apenas para os governadores de Santa Catarina e Tocantins ${ }^{8}$. Deve-se considerar, também, que o Executivo estadual, apesar de suas prerrogativas constitucionais, não possui uma força comparável à do Executivo nacional, dadas as próprias características do arranjo federativo que limitam bastante o escopo das competências dos estados. Além disso, o alcance de tais prerrogativas pode ser diferente entre os estados em virtude das características da estruturação do sistema partidário, dos padrões de competição política, do nível de desenvolvimento institucional do Legislativo, entre outros (GroHmAN, 2001; SANTOS, 2001). Este aspecto é enfatizado por Tomio (2006) que, estudando o processo legislativo no estado de Santa Catarina, afirma que o poder dos governadores de editar medidas provisórias é bem mais restrito do que

\footnotetext{
7 Tais restrições são possíveis porque, apesar da prerrogativa da urgência ser assegurada ao governador constitucionalmente, é prerrogativa privativa do Legislativo elaborar seu Regimento Interno.

8 Em outros dois estados brasileiros (Piauí e Acre), os governadores têm à disposição o poder constitucional de editar Medida Provisória.
} 
o garantido ao presidente e não pode ser visto como determinante dos índices elevados de aprovação da agenda legislativa dos chefes do Executivo.

Assim como no processo legislativo nacional, os partidos políticos desempenham importante papel na coordenação dos trabalhos legislativos. Possuem, em diferentes graus, prerrogativas importantes que permitem aos líderes partidários influenciar a agenda e o ritmo dos trabalhos legislativos e extrair de suas bancadas um comportamento disciplinado. Além disso, cargos e recursos são distribuídos a partir de critérios partidários e a mobilização de várias prerrogativas legislativas depende de coordenação partidária. Entretanto, deve-se considerar que o poder dos partidos na arena parlamentar no nível estadual não é idêntico ao que se observa na arena nacional.

Observa-se, em relação aos 12 estados aqui abordados, que nem todos os recursos disponíveis aos líderes partidários na Câmara dos Deputados estão previstos nas Assembleias Estaduais. Além disso, há importantes variações entre as unidades - no que se refere, por exemplo, à prerrogativa de determinar a agenda do plenário juntamente com o Presidente da Casa e ao direito de solicitar urgência e encaminhar as votações nas comissões. Em todos os estados investigados oferecem aos líderes a prerrogativa de indicar membros para compor as comissões permanentes, assim como ocorre em âmbito nacional. O mesmo, entretanto, não se verifica quanto ao poder de substituição desses membros. Apenas em seis Assembleias - CE, PA, PE, RJ, SP e TO ${ }^{9}$ - o Regimento Interno afirma explicitamente que os líderes podem substituir os membros das comissões a qualquer momento e circunstância. Essa prerrogativa garante às lideranças o poder de punir comportamentos indisciplinados e manipular a composição das comissões em momentos de votações importantes.

Tanto a Câmara dos Deputados quanto as Assembleias Estaduais são compostas por sistema proporcional e, em seu interior, as comissões são compostas proporcionalmente à força dos partidos ou blocos parlamentares representados. Em ambas as esferas, as comissões parlamentares não contam com prerrogativas como as controladas por essas instâncias na House norte-americana, que Ihes dão vantagens em relação ao Plenário no processo legislativo. O poder conclusivo das comissões, quando previsto, é restrito a matérias com poucos efeitos distributivos ou sobre a ordem jurídica. Tampouco a sequência das jogadas beneficia as comissões das Assembleias Estaduais, já que é ao Plenário que cabe a palavra final sobre as matérias.

Entre os 12 estados investigados, 9 preveem o poder conclusivo das comissões ${ }^{10}$. Em geral, a prerrogativa está restrita a projetos que dispensam a competência do Plenário. Apenas o Regimento Interno da Assembleia de Minas Gerais é específico quanto a essa questão, restringindo o poder conclusivo a projetos de lei que versem sobre declaração de utilidade pública, denominação de prédios públicos, projetos de resolução que tratem de subvenções, requerimentos escritos que solicitarem providência a órgão da administração pública, manifestação de pesar por falecimento de membro do

\footnotetext{
9 Os regimentos são ambíguos em relação à questão da substituição de membros. Considerou-se aqui apenas os estados nos quais os regimentos afirmam explicitamente que os líderes podem substituir os membros das comissões a qualquer momento e circunstância.

${ }^{10}$ A prerrogativa não está prevista apenas no Pará, Pernambuco e Tocantins. Nos demais estados, para que a matéria sujeita ao poder conclusivo das comissões seja votada em Plenário, é necessário recurso assinado por $1 / 10$ dos membros da casa. A exceção é Santa Catarina, que exige a assinatura de 2/10 dos parlamentares.
} 
ROCHA, M. M.; COSTA, A. Percepções dos deputados estaduais sobre o sistema...

poder público, manifestações de apoio, aplauso, regozijo ou congratulações, manifestação de repúdio ou protesto. Trata-se, portanto, de matérias com pouco impacto sobre o status quo e reduzidos efeitos distributivos

A variação é maior quando se trata da estrutura do sistema de comissões nos estados investigados. Por exemplo, o número de comissões permanentes varia de 9 no Rio Grande do Sul a 36 no Rio de Janeiro e o número de membros por comissão também varia bastante. As comissões mais comuns às Assembleias são as dedicadas à análise dos aspectos da constitucionalidade das proposições de lei e de sua adequação financeira e orçamentária. No tocante às comissões de análise de mérito, as mais comuns são as de saúde, educação, agricultura e pecuária, segurança pública, meio ambiente, direitos humanos, direitos do consumidor entre outras. Embora caiba a todas as comissões realizar a fiscalização do Poder Executivo, vários estados possuem uma comissão especialmente voltada para essa finalidade. É possível encontrar variações nos tipos de comissões em virtude da diferença na saliência de determinados temas em cada estado.

Observa-se que também nas Assembleias Estaduais verificam-se algumas das características institucionais que, segundo a literatura, contribuem para fragilizar as comissões enquanto instâncias decisórias. Por outro lado, também é possível identificar diferenças importantes, sobretudo no tocante à forma como está estruturado o sistema de comissões. Por essa razão, é razoável crer que haja importantes variações na dinâmica política entre os estados, não sendo possível fazer afirmações conclusivas sobre o peso parlamentar dos partidos políticos, o grau de preponderância exercida pelo Executivo no processo legislativo e, por conseguinte, sobre o desempenho das comissões parlamentares nos legislativos estaduais. É justamente por essa razão que alguns autores recomendam maior cuidado ao transplantar a lógica política nacional para a totalidade dos estados da federação brasileira (SANTOS, 2001, p. 289; SOUZA e DANTAS NETO, 2006).

\section{Comissões Parlamentares nos Legislativos Estaduais Brasileiros: o que pensam os Parlamentares}

Como afirmam Ricci e Lemos (1997), a consideração dos aspectos assinalados pelos estudiosos do Poder Legislativo brasileiro conduzem à conclusão de que as comissões permanentes exercem um papel apenas secundário no processo decisório. De modo geral, tem prevalecido uma visão das comissões parlamentares como arenas pouco institucionalizadas, frágeis, incapazes de fazer valer suas posições perante os partidos políticos, o Plenário e o Poder Executivo. Nesta seção, pretende-se confrontar os aspectos assinalados pela literatura com as percepções dos deputados estaduais brasileiros. São quatro as questões a serem discutidas. Primeiro, em que medida as percepções dos deputados estaduais convergem com as conclusões da literatura sobre o funcionamento e o desempenho das comissões parlamentares? Segundo, é possível afirmar que a dinâmica política nacional replica-se na arena estadual tendo como resultado comissões parlamentares política e institucionalmente fracas em comparação com as outras instâncias decisórias? Terceiro, quais as razões apresentadas pelos deputados para explicar a importância relativa das instâncias decisórias das Assembleias, a saber, as comissões permanentes, o Plenário e a Mesa Diretora? Quarto, que outros aspectos não destacados pela 
literatura devem ser considerados no estudo do funcionamento e do desempenho do sistema de comissões ${ }^{11}$ ?

Os dados aqui analisados resultaram da pesquisa "Trajetórias, perfis e padrões de interação de legisladores estaduais em doze unidades da federação". A Tabela 1 parece corroborar a visão da literatura de que as comissões parlamentares são instâncias secundárias no processo legislativo e não exercem, nos legislativos estaduais, as funções importantes de suas congêneres norte-americanas.

Tabela 1

Instância decisória mais importante da Assembleia Estadual ${ }^{12}$

\begin{tabular}{|c|c|}
\hline Instância decisória & $\mathbf{( \% )}$ \\
\hline Plenário & $54,8 \%$ \\
\hline Mesa Diretora & $26,3 \%$ \\
\hline Comissões Permanentes & $16,6 \%$ \\
\hline NS/NR & $2,3 \%$ \\
\hline Total & $100,0 \%$ \\
\hline Fonte: Banco de Dados Pesquisa Trajetórias, perfis e padrões de interaça de
\end{tabular}

padrões de interação de

legisladores estaduais em doze unidades da federação - CEL-DCP.UFMG

Em uma questão seguinte, perguntou-se aos deputados porque, em sua opinião, a instância assinalada por ele era a mais importante em sua Assembleia. A questão, em formato aberto, deu aos deputados liberdade para se expressarem. Por esta razão foi comum, em uma única resposta, os deputados assinalarem mais de uma razão. Optamos por analisar todas as dimensões assinaladas pelos deputados em suas respostas como forma de apreender o máximo de informação. Assim, naquelas respostas em que os deputados se referem a mais de uma dimensão, a resposta foi desagregada em duas ou mais, de modo que o total de frequências não equivale ao total de deputados. Esse esclarecimento é importante porque: (a) pode-se aventar haver uma diferença importante entre os deputados que assinalaram uma única razão e os parlamentares que assinalaram mais de um aspecto e (b) porque a sobrevalorização de algumas dimensões pode refletir o número de vezes em que ela foi a única assinalada pelo deputado e o número de vezes em que ela apareceu ao lado de outros aspectos em uma mesma resposta.

A Tabela 2 apresenta as dimensões assinaladas pelos deputados que afirmaram, na questão anterior, que as comissões permanentes eram as instâncias mais importantes de sua Casa legislativa e o número de referências a cada dimensão. Na Tabela, são apresentadas todas as dimensões, incluindo as menos frequentes. Na categoria "outros" foram agrupadas as respostas ambíguas, cujo sentido foi difícil de compreender, as que não correspondiam ao questionamento feito ou as que receberam apenas uma citação.

\footnotetext{
11 Obviamente, não se espera que as razões apresentadas pelos parlamentares sejam elaboradas em termos acadêmicos. O objetivo é verificar se as dimensões mais destacadas nos estudos sobre comissões encontram eco nas percepções e opiniões dos deputados estaduais.

${ }^{12}$ A questão foi elaborada da seguinte forma: "Qual instância decisória - Mesa Diretora, Comissões Permanentes ou Plenário - é, de fato, a mais importante nesta Assembleia Legislativa?".
} 
ROCHA, M. M.; COSTA, A. Percepções dos deputados estaduais sobre o sistema...

Tabela 2

Dimensões destacadas pelos deputados para explicar porque consideravam as COMISSÕES PERMANENTES as instâncias decisórias mais importantes em sua Casa legislativa ${ }^{13}$

\begin{tabular}{|l|c|}
\hline \multicolumn{1}{|c|}{ Dimensões } & $\begin{array}{c}N^{\circ} \text { de } \\
\text { referências }\end{array}$ \\
\hline Espaço de debate/discussão & 30 \\
\hline Poder decisório 1 - Espaço onde ocorrem as decisões & 12 \\
\hline Poder decisório 2 - Reverência do Plenário em relação à posição definida nas comissões & 7 \\
\hline Poder decisório 3 - Espaço onde ocorrem as votações & 6 \\
\hline Espaço de avaliação/estudo/aprofundamento/análise & 12 \\
\hline Oportunidades para a participação dos cidadãos/interlocução com a sociedade & 10 \\
\hline Poder de veto/importância da CCJ & 5 \\
\hline Espaço para a realização de acordos/negociação & 5 \\
\hline Poder de veto & 4 \\
\hline Poder de modificar as proposições & 4 \\
\hline Rota obrigatória de todas as proposições/sequência do processo & 3 \\
\hline Oportunidades para a participação direta dos parlamentares & \\
\hline Oportunidades para a fiscalização & 2 \\
\hline Espaço para a elaboração de pareceres & 2 \\
\hline Outros & \\
\hline Total & \\
\hline Fonte: Banco de Dados Pesquisa Trajetorias, perfis padros de interação de legisladores estaduais & \\
\hline
\end{tabular}

Fonte: Banco de Dados Pesquisa Trajetórias, perfis e padrões de interação de legisladores estaduais em doze unidades da federação - CEL-DCP.UFMG

Foi possível distinguir 14 dimensões enfatizadas nas respostas dos deputados. A dimensão mais recorrente corresponde às oportunidades que as comissões oferecem para o debate/discussão, com 30 referências. Segundo os parlamentares, é nas comissões que ocorre a "discussão democrática das questões ligadas aos projetos e às posições políticas" ou, em seu âmbito, "há todos os debates, reflexões sobre determinados projetos ${ }^{14 "}$.

A segunda dimensão mais citada refere-se ao poder de decisão das comissões. Nas respostas de 25 parlamentares, foi enfatizado que as comissões são as instâncias onde realmente ocorrem as decisões. Essas respostas, no entanto, podem ser agrupadas em três categorias (Poder decisório 1, 2 e 3): 12 deputados referiram-se de forma vaga à capacidade decisória das comissões afirmando que "lá que resolve as coisas, quando chega no Plenário já tá resolvido" ou que as comissões têm "capacidade de decisão e decisão política" ou que é em seu âmbito que "os projetos e emendas são decididos". Sete deputados se referiram mais especificamente à reverência do Plenário em relação às decisões tomadas nas comissões, afirmando que "90\% dos pareceres das comissões são acatados pelo Plenário" ou que "as questões são todas resolvidas nas comissões, o Plenário apenas acaba referendando as decisões das comissões". Por fim, seis parlamentares destacaram o aspecto da agregação, afirmando que "os projetos são altamente votados nas comissões" ou que nelas "se define e aprova ou não os projetos de maior importância para o estado".

\footnotetext{
13 Nesta questão perguntou-se aos deputados: "Pode me explicar POR QUE o (a) Sr (a) considera essa instância, de fato, a mais importante?"

14 Deste ponto em diante, todas as citações entre aspas correspondem às respostas dadas pelos deputados da forma como expressas por eles e anotado pelo entrevistador. A reprodução de algumas respostas tem o objetivo de destacar as diferentes maneiras pelas quais os deputados se referiram às dimensões analisadas.
} 
OPINIÃO PÚBLICA, Campinas, vol. 18, n², novembro, 2012, p. 278-308

As dimensões da avaliação/estudo/aprofundamento/análise e da participação dos cidadãos/interlocução com a sociedade foram, respectivamente, a terceira e a quarta dimensões mais citadas com 12 e 10 referências. Os parlamentares assinalaram, em diferentes termos, que as comissões oferecem oportunidades "de analisar mais a fundo e decidir sobre os projetos" ou que "o estudo dos temas se dá nas comissões". Outros destacaram as oportunidades oferecidas pelas comissões para uma interlocução dos representantes com os cidadãos, afirmando que a comissão "é a porta de entrada do cidadão" ou que nela é onde "há participação direta dos cidadãos".

Aspectos citados com menor frequência referiam-se à importância da Comissão de Constituição e Justiça (CCJ) devido ao seu poder de veto; às oportunidades oferecidas pelas comissões para a construção de acordos e para uma participação mais efetiva e direta do parlamentar individual; entre outros. Apenas dois parlamentares destacaram a função da fiscalização como uma razão para justificar a importância das comissões ${ }^{15}$.

Se o reduzido número de parlamentares que afirmaram que as comissões são as instâncias mais importantes da Assembleia corrobora a visão da literatura sobre o papel secundário dessas instâncias no processo legislativo, o mesmo não ocorre em relação às razões que, segundo essa minoria, fazem das comissões arenas importantes.

Parece razoável supor que, por serem colegiados menores nos quais é possível a interação facea-face entre os deputados, as comissões possam converter-se em arenas deliberativas nas quais os parlamentares, por meio da troca de argumentos e informações, engajem-se em um processo de formação e transformação de preferências e de persuasão mútua. E para parte significativa dos deputados que veem as comissões como as instâncias mais importantes da Assembleia, isso não apenas corresponde a um dos papéis das comissões como, também, é a principal razão de sua relevância. Entretanto, as dimensões do debate e da discussão têm sido amplamente negligenciadas pelos estudos legislativos. Em geral, os estudiosos mostram-se céticos sobre a possibilidade de as comissões constituírem-se em arenas deliberativas, em geral, por razões semelhantes pelas quais não se acredita que elas possam cumprir um papel informacional (FIGUEIREDO e LIMONGI, 1999; PEREIRA e MUELLER, 2000).

Outra incongruência entre a visão da literatura e as percepções dos parlamentares é observada em relação ao segundo aspecto mais frequente em suas respostas. Os estudiosos do Legislativo tendem a destacar a ausência ou a falta de efetividade das prerrogativas decisórias das comissões como fatores que as tornam arenas frágeis e pouco importantes no processo decisório. Nesse sentido, é surpresa constatar que alguns deputados expliquem a importância das comissões pelo seu poder e capacidade decisórias. Embora afirme que é nas comissões onde ocorrem as decisões, onde se decide a aprovação ou rejeição dos projetos e que o Plenário acata as decisões das comissões, não ficam claros, pelas respostas dos parlamentares, os mecanismos que explicariam essa capacidade decisória. Dado o

\footnotetext{
15 As dimensões que receberam menos destaque pelos parlamentares são discutidas por Lemos (2006) e Ribeiral (1998), que argumentam que os deputados tendem a atribuir mais importância a algumas comissões, entre elas, a que avalia os aspectos da constitucionalidade das proposições de lei; e por Lemos (2006) e Santos (1998) que enfatizam as oportunidades oferecidas pelas comissões para uma participação mais direta, autônoma e efetiva dos deputados.
} 
ROCHA, M. M.; COSTA, A. Percepções dos deputados estaduais sobre o sistema...

reduzido escopo do poder conclusivo e os obstáculos destacados pela literatura ao funcionamento das comissões, fica em aberto compreender como elas são capazes de sobrepor-se ao Plenário e às outras instâncias decisórias da Casa.

Uma possível resposta pode ser encontrada nas oportunidades oferecidas pelas comissões, seja para a avaliação, estudo e análise dos projetos, seja para um maior envolvimento dos cidadãos no processo decisório, dimensões que, juntas, receberam 22 referências. Para alguns deputados, portanto, não seriam tanto as funções legislativas que tornariam as comissões instâncias relevantes, mas o fato de elas serem, como afirmou um parlamentar, "a porta de entrada do cidadão" ou por oferecerem oportunidades para a redução da incerteza que cerca as decisões, como propala o modelo informacional de organização legislativa. Esse aspecto tem sido destacado por alguns estudos que mostram a importância dos mecanismos de participação para o fortalecimento das comissões e do Legislativo como um todo (ANASTASIA, 2001; ANASTASIA e INÁCIO, 2010).

As respostas dos deputados parecem corroborar a conclusão da literatura de que as comissões brasileiras não se convertem em espaços propícios à realização de acordos e à produção de ganhos de troca, dimensão muito pouco enfatizada pelos deputados. Não houve qualquer menção à importância das comissões para a atuação das oposições e das minorias. Também é interessante notar que a função fiscalizadora das comissões não tenha recebido destaque nas respostas dos legisladores, a despeito dos regimentos internos das Assembleias destacarem a sua função de controle. Em geral, os regimentos determinam que cabe às comissões exercer a fiscalização e o controle dos atos da administração pública direta e indireta, bem como o acompanhamento e a fiscalização contábil, financeira e orçamentária. Entre os 12 estados investigados, nove possuem comissão voltada especificamente para fiscalização financeira e orçamentária ${ }^{16}$.

É interessante também notar que foi comum o fato da dimensão do debate e da participação terem aparecido juntas em uma mesma resposta. Alguns parlamentares justificaram sua visão das comissões como instâncias mais importantes afirmando que: "(...) nelas há mais tempo para discussão e se abre mais para a participação da sociedade", "(...) se discute e aprofunda os debates sobre os projetos de lei e onde se abre para a participação da sociedade civil", "(...) é onde mais se aprofunda o debate, inclusive com participação popular", e que nas comissões ocorre a "interlocução com a sociedade e discussão profunda dos projetos de lei". Respostas como estas parecerem sugerir que, para alguns deputados, a dimensão do debate se associa à dimensão da participação de forma produtiva.

Cabe agora analisar as razões apontadas pelos parlamentares que assinalaram que a Mesa Diretora e o Plenário são as instâncias mais importantes da Casa. Essa é uma forma indireta de verificar se os fatores apontados pela literatura para explicar a fragilidade das comissões parlamentares encontram eco nas percepções dos legisladores.

A Tabela 3 mostra as dimensões destacadas pelos deputados que afirmaram que a MESA DIRETORA é a instância mais importante da Casa para justificar sua resposta:

\footnotetext{
${ }^{16}$ São eles: Minas Gerais, Bahia, Rio de Janeiro, São Paulo, Tocantins (inclusive Comissão de Fiscalização dos Programas de Governo), Ceará, Rio Grande do Sul, Pará e Mato Grosso.
} 
OPINIÃO PÚBLICA, Campinas, vol. 18, n², novembro, 2012, p. 278-308

Tabela 3

Dimensões destacadas pelos deputados para explicar porque consideravam a MESA DIRETORA a instância decisória mais importante em sua Casa legislativa

\begin{tabular}{|l|c|}
\hline \multicolumn{1}{|c|}{ Dimensões } & $\begin{array}{c}\text { Número de } \\
\text { referências }\end{array}$ \\
\hline Poder decisório & 26 \\
\hline Poder de pauta & 23 \\
\hline Poder de organizar/conduzir os trabalhos & 23 \\
\hline Concentração de poder 1 - Organização presidencialista & 16 \\
\hline Concentração de poder 2 - Concentração de poder em torno da Mesa & 12 \\
\hline Concentração de poder 3 - Concentração de poder em torno do presidente da Casa & 6 \\
\hline Poder de gestão de recursos administrativos e financeiros & 7 \\
\hline Relação com as bancadas partidárias & 6 \\
\hline Passagem obrigatória de todos ou da maioria dos projetos e das decisões & 5 \\
\hline Sequência do processo legislativo & 5 \\
\hline Representatividade/método de composição & 4 \\
\hline Relação com o governo estadual & 3 \\
\hline Outros & 18 \\
\hline Total & 154 \\
\hline
\end{tabular}

Fonte: Banco de Dados Pesquisa Trajetórias, perfis e padrões de interação de legisladores estaduais em doze unidades da federação - CEL-DCP.UFMG

Foi possível destacar 12 dimensões nas respostas dos 135 deputados para justificar por que a Mesa Diretora era a instância mais importante da Casa. Em conjunto, essas 12 dimensões somaram 136 referências. Foram agrupadas 18 respostas em "Outros", por apresentarem sentido ambíguo ou vago ou por terem recebido apenas uma referência.

A resposta mais frequente dos deputados para justificar porque eles consideravam a Mesa Diretora a instância decisória mais importante da Casa fazia referência ao poder de decisão da Mesa. Foram agrupadas nessa categoria todas as respostas que se referiam ao poder decisório da Mesa, incluindo as mais vagas como "é onde as decisões ocorrem" ou "é onde realmente são aprovadas todas as decisões". Também foi comum afirmar que as decisões mais importantes ocorrem no âmbito da Mesa. Em suma, em todas essas respostas, os deputados justificaram a importância da Mesa Diretora pelo seu poder de influir ou determinar o rumo das decisões. Essa justificativa esclarece pouco sobre as razões da importância da Mesa Diretora, uma vez que acaba por cair em um argumento circular, no qual se afirma que a Mesa Diretora é a instância decisória mais importante da Casa porque possui poder decisório ou porque todas ou as decisões mais importantes ocorrem nela. Com base nas demais respostas, é possível aventar a hipótese de que esse poder decisório tem origem nas prerrogativas reservadas aos membros da Mesa Diretora, sobretudo ao seu presidente, mais especificamente, o poder de exercer controle sobre a pauta e sobre os recursos administrativos e financeiros sem os quais os parlamentares não poderiam exercer adequadamente seu mandato.

A concentração de poderes em torno da Mesa Diretora e/ou de seu presidente foi um aspecto bastante destacado pelos parlamentares, sendo possível encontrar 34 referências a essa dimensão. Estas foram agrupadas em três categorias diferentes (Concentração de poder 1,2 e 3 ) de modo a permitir uma análise mais precisa. A organização presidencialista da Casa como razão que explica sua importância decisória foi literalmente citada por 16 parlamentares. Afirmou-se que "a Casa é um regime presidencialista. Quem manda é o presidente. Nada acontece se o presidente não quiser" e que a Mesa 
ROCHA, M. M.; COSTA, A. Percepções dos deputados estaduais sobre o sistema...

"é que controla a Casa como se houvesse um presidencialismo dentro do legislativo". Outros 12 parlamentares referiam-se, de modo geral, à concentração de poderes em torno da Mesa, o que, segundo eles, permite a seus membros manipular as regras do jogo e controlar todo o trabalho legislativo. Seis parlamentares destacaram, de forma mais específica, a concentração de poderes em torno do presidente da Casa afirmando, por exemplo, que "o presidente tem em suas mãos o poder".

A dimensão mais citada, em segundo lugar, refere-se ao poder de pauta da Mesa Diretora. Nesse caso, os parlamentares foram bastante específicos ao afirmar que a importância da Mesa advém de seu poder regimental de decidir o que vai ou não ser votado em Plenário e de definir o ritmo dos trabalhos legislativos. Afirmou-se que é a Mesa "quem conduz e pauta os trabalhos", "é quem pauta a Casa e define a agenda", é "quem decide o que realmente irá a Plenário" ou "arquiva o que não é do seu interesse".

Dimensão igualmente frequente refere-se às atribuições das Mesas Diretoras em diferentes Assembleias de organizar e conduzir os trabalhos legislativos. No tocante a essa dimensão, os parlamentares foram mais vagos, não destacando um aspecto particular. De fato, os Regimentos Internos das Assembleias Estaduais reservam um importante espaço de atuação para os órgãos de direção da Casa. Semelhantemente ao que ocorre na Câmara dos Deputados, a Mesa Diretora, nas Assembleias Estaduais, são responsáveis pela direção dos trabalhos legislativos, pela definição da Ordem do Dia e retirada de proposições da pauta, além da decisão a respeito de requerimentos. Outras dimensões destacadas, porém com menos frequência, foram o poder da Mesa de gerir os recursos administrativos e financeiros, cruciais para o exercício do mandato dos deputados; a relação dessa instância com as bancadas partidárias e sua capacidade de agir como conciliadora e articuladora junto aos partidos e aos líderes partidários.

Alguns deputados destacaram como razões da importância da Mesa Diretora o fato de essa instância ser passagem obrigatória de todos ou da maioria dos projetos e das decisões da Casa ("Todos os temas passam obrigatoriamente por ela"). Outros chamaram a atenção para a sequência do processo, afirmando que "é a Mesa que tem o poder decisório. A última palavra é dela" ou que "tudo passa pela Mesa Diretora antes de seguir para o Plenário ou para as comissões". Apenas três parlamentares referiram-se às relações entre a Mesa Diretora e o governo/Poder Executivo como um fator que explica a importância daquela instância.

Observa-se grande convergência entre as percepções dos deputados em relação à importância da Mesa Diretora e os aspectos destacados pela literatura. Estudos em nível nacional destacam que, na Câmara dos Deputados, essa instância tem "prerrogativas e competências abrangentes, exercidas majoritariamente pelo seu presidente, que asseguram à Mesa o controle da agenda legislativa" (INÁCIO, 2007, p.202). Segundo a autora, o poder de agenda do presidente é um aspecto relevante, pois este ator é responsável por um conjunto de decisões sobre os trabalhos legislativos que vai da definição das proposições a serem apreciadas em Plenário (ouvido o Colégio de Líderes) à concessão da palavra aos parlamentares durante as sessões deliberativas e o despacho de requerimentos de deputados e líderes. "Consequentemente, as decisões do presidente da Mesa definem as oportunidades de participação do legislador individual nos trabalhos legislativos, que são, em boa medida, restritas à atuação em Plenário" 
OPINIÃO PÚBLICA, Campinas, vol. 18, n², novembro, 2012, p. 278-308

(INÁcIO, 2007, p.203). Figueiredo e Limongi (1999) também chamam atenção para esse ponto ao destacarem a centralização dos trabalhos legislativos em torno da Mesa Diretora e do Colégio de Líderes.

A decisão, por exemplo, sobre quais projetos aprovados nas comissões entrarão ou não na Ordem do Dia fica a cargo da Mesa.

A Tabela 4 mostra as dimensões destacadas pelos deputados que afirmaram que o PLENÁRIO é a instância mais importante da Casa para justificar sua resposta:

Tabela 4

Dimensões destacadas pelos deputados para explicar porque consideravam o PLENÁRIO a instância decisória mais importante em sua Casa legislativa

\begin{tabular}{|c|c|}
\hline Dimensões & $\begin{array}{l}\text { Número de } \\
\text { referências }\end{array}$ \\
\hline Poder de decisão 1/ Última etapa do processo & 75 \\
\hline Poder de decisão 2/ Espaço onde ocorrem as decisões & 35 \\
\hline Poder de decisão 3 /Espaço onde ocorrem as votações & 18 \\
\hline Soberania & 38 \\
\hline Presença/decisão da maioria & 31 \\
\hline Espaço de debate & 28 \\
\hline Arena mais representativa & 21 \\
\hline Rota obrigatória de todas as proposições & 12 \\
\hline Arena mais democrática & 11 \\
\hline Maior visibilidade e transparência & 5 \\
\hline Fraco poder das comissões & 3 \\
\hline Outros & 37 \\
\hline Total & 314 \\
\hline
\end{tabular}

As respostas dadas pelos 281 parlamentares que afirmaram que o Plenário é a instância mais importante da Casa foram reunidas em 11 dimensões. As respostas com sentido vago ou ambíguo ou com apenas uma referência foram agrupadas em "Outros".

Chama a atenção o elevado número de referências ao poder de decisão associado ao Plenário. No total, foram 128 referências a essa dimensão, agrupadas em três subgrupos (Poder decisório 1, 2 e 3; 75 deputados fizeram menção ao fato de que o Plenário é a última etapa de tramitação de uma proposição, sendo suas decisões de caráter definitivo. Destes, 12 foram mais específicos referindo-se ao poder do Plenário de reverter decisões, recomendações e pareceres dados por outras instâncias como a Mesa Diretora e as comissões permanentes. O poder decisório do Plenário foi apontado por 35 deputados de forma vaga, afirmando que o Plenário é a arena "que decide; as demais são intermediárias", que "detém o poder para tomar toda e qualquer decisão", que "decide sobre aprovação/rejeição das matérias" e que "contra a vontade expressa em Plenário nem a mesa nem as comissões têm força". Dezoito deputados se referiram ao poder decisório do Plenário pelo fato de que nele ocorre a agregação das preferências, isto é, é a instância na qual os projetos são votados, aprovados e rejeitados.

A soberania do Plenário e de suas decisões foi apontada por 38 deputados. Essa dimensão poderia ter sido agrupada junto ao "Poder decisório 1", que se refere ao fato de o Plenário ser a última etapa de decisão. No entanto, optou-se por mantê-la separada, dada a especificidade das respostas. 
ROCHA, M. M.; COSTA, A. Percepções dos deputados estaduais sobre o sistema...

Essa opinião evidencia que a percepção dos parlamentares sobre a importância do Plenário está estreitamente associada ao caráter absoluto e irreversível de suas decisões, às quais não cabe recurso ou outro mecanismo legislativo que possa alterar os resultados.

Justificar a escolha pelo Plenário como instância mais importante por seu caráter coletivo e pela presença da maioria e/ou de todos os deputados foi a escolha de vários deputados. São 31 referências ao fato de que essa arena oferece a oportunidade para a participação de todos e nela vence a posição majoritária. Duas outras dimensões parecem associadas a esta: o caráter mais democrático do Plenário e o fato de tratar-se da instância mais representativa, com 11 e 21 referências, respectivamente. Com isso, os deputados enfatizam o fato de que, das instâncias decisórias da Assembleia, apenas o Plenário contempla a participação efetiva de todos os parlamentares e das diferentes visões representadas na Casa no processo de tomada de decisões. Afirmou-se que "é o Plenário que decide democraticamente", que nessa instância "se ouve todos os deputados de forma democrática", que o Plenário "é a instância onde a população se encontra representada", que "expressa a opinião de diversas agremiações partidárias" e, ainda, que "o Plenário é o coração da Casa. Onde interagem todos os anseios, vontades da Casa. Nas comissões é mais restrita a participação".

É surpreendente constatar 28 referências que atribuíam a importância do Plenário aos debates e discussões ocorridos em seu âmbito. A grande maioria dos estudos sobre deliberação associa o debate e o processo de argumentação a arenas menores, nas quais é possível a interação face-a-face entre os participantes. Em se tratando dos órgãos legislativos, é comum atribuir às comissões - e não ao Plenário - a função de permitir o debate. De fato, parece difícil que, em legislativos compostos por 94, 77 ou mesmo 63 membros $^{17}$, os deputados possam se engajar em um processo discursivo no qual todos tenham a oportunidade de falar e serem ouvidos, especialmente se for considerada a escassez de tempo e a urgência envolvida em algumas decisões. Nesse sentido, é provável que os parlamentares que responderam dessa forma não estivessem fazendo referência a um processo efetivamente deliberativo com a participação igualitária de todos e sim à fase da discussão que antecede a votação, na qual o direito à palavra é desigualmente distribuído entre líderes e liderados e entre os proponentes e relatores dos projetos. Também é bom lembrar que algumas Assembleias Legislativas pesquisadas são bastante pequenas.

Outros aspectos enfatizados pelos parlamentares referiam-se ao fato de o Plenário ser rota obrigatória de todas as proposições e à maior visibilidade e transparência de suas decisões. Apenas três parlamentares justificaram a importância do Plenário pela falta de poder das comissões permanentes.

A maioria das respostas dadas pelos parlamentares corrobora a conclusão da literatura de que a centralização decisória desloca o processo legislativo para o Plenário em detrimento das comissões. Grande parte das respostas (128 referências) mostra que os parlamentares, no entanto, não atribuem esse deslocamento aos poderes das lideranças partidárias, entre eles o de pedir urgência na tramitação dos projetos, que não recebeu nenhuma referência. Eles tendem a atribuir essa importância muito mais à sequência do processo legislativo, definida pelos regimentos internos das Assembleias Estaduais, que

\footnotetext{
${ }^{17}$ Refere-se aqui, especificamente, às Assembleias de SP, MG e BA.
} 
OPINIÃO PÚBLICA, Campinas, vol. 18, n², novembro, 2012, p. 278-308

garante ao Plenário a possibilidade de dar a última palavra sobre as proposições, o que torna suas decisões soberanas e irrevogáveis. Devido à ênfase dada pela literatura aos efeitos da prerrogativa da urgência dos líderes parlamentares e do Executivo, é realmente surpreendente que nenhum parlamentar tenha se referido a esta regra para explicar a importância relativa das arenas decisórias da Assembleia.

Merece destaque, também, o fato de que tenha havido 63 referências ao caráter majoritário, coletivo, democrático e representativo do Plenário como principal razão para justificar sua importância. Esse aspecto merecerá uma análise mais detida nas próximas páginas.

\section{0 que os dados revelam}

A análise dos dados permite mapear alguns aspectos importantes a nortear futuras investigações sobre o funcionamento e desempenho das comissões permanentes nos legislativos estaduais brasileiros. Parece promissor, por exemplo, investigar em que medida a função de análise e estudo própria das comissões, assim como as oportunidades oferecidas por elas para o debate e a discussão e para a participação dos cidadãos e grupos organizados, contribui para ampliar sua relevância no processo legislativo, a despeito da ausência de outras prerrogativas geralmente enfatizadas pela literatura como centrais para o bom desempenho dessas instâncias. 0 caso da Assembleia de Minas Gerais, por exemplo, que se destaca pelo trabalho realizado pelas audiências públicas e como a Casa que apresentou o maior percentual de parlamentares que consideraram as comissões as instâncias mais importantes, reforça a importância dessa agenda de pesquisa (ANASTASIA, 2001).

A ausência de respostas que destacassem a dimensão da fiscalização leva à pergunta de por que, a despeito de regimentalmente terem uma importante função fiscalizadora, as comissões, na percepção dos legisladores, não se destacam pelo controle. Caberia investigar se isso seria um reflexo da falta de efetividade do controle dos Legislativos sobre os Executivos estaduais nos moldes propostos por Abrúcio (1998) ou o resultado de outros fatores. De modo geral, como salientam alguns autores, apesar de haver mais fiscalização nos dias atuais, o controle parlamentar é uma função que recebe muito menos importância do que as demais atividades comuns ao exercício parlamentar. Muitas vezes, controlar o Executivo pode acarretar atritos com grupos, pessoas e com o governo que detém controle sobre importantes recursos. Além disso, pode resultar no bloqueio de obras e políticas públicas, ao invés de sua promoção, e envolver esforços e tempo que poderiam ser direcionados a atividades que geram dividendos eleitorais imediatos e mais tangíveis (LEMOS, 2006; ROSENTHAL, 1981; LLANOS e MUSTAPIC, 2005). Além disso, como salienta Lemos (2006), o controle das comissões parlamentares voltadas para a fiscalização por partidos que compõem a coalizão de governo pode comprometer seu desempenho.

Uma incongruência importante entre as percepções dos deputados e as visões da literatura diz respeito à importância da centralização decisória em torno do Poder Executivo para explicar a fragilidade das comissões. Nas respostas dos parlamentares para justificar porque a Mesa ou o Plenário são as instâncias mais importantes da Casa, foram encontradas apenas sete referências aos termos "Executivo", "governo" ou "governador".

Na visão dos deputados estaduais, não são as prerrogativas constitucionais do governador que conduzem os trabalhos e as decisões legislativas para a Mesa ou para o Plenário, aumentando a 
ROCHA, M. M.; COSTA, A. Percepções dos deputados estaduais sobre o sistema...

importância dessas instâncias e impedindo que as comissões desempenhem um papel de relevo no processo. Segundo a percepção de grande parte dos legisladores, a explicação estaria na centralização dentro do próprio Poder Legislativo, decorrente da forma como as prerrogativas são distribuídas entre os seus diferentes órgãos. Além disso, a variável centralização decisória foi enfatizada para explicar a importância da Mesa Diretora e não do Plenário.

Não houve nenhuma referência à concentração de poderes em torno dos líderes de bancadas partidárias. Esse fato permite levantar a hipótese de que a centralização decisória no âmbito das Assembleias Estaduais explicar-se-ia mais pelas prerrogativas reservadas à Mesa Diretora do que pelos poderes das lideranças partidárias. A inclusão da alternativa "Colégio de Líderes" poderia ter contribuído para refinar a investigação sobre esse aspecto. Entretanto, nem todas as Casas possuem um colegiado de lideranças formalmente reconhecido. Certamente, essas evidências não são suficientes para questionar a centralidade dos partidos na determinação da agenda e do ritmo do processo legislativo e a capacidade dos líderes para disciplinar suas bancadas. Por outro lado, parece ser mais uma evidência a motivar novas investigações sobre o papel dos partidos políticos e sobre o impacto de suas prerrogativas no processo legislativo estadual.

Uma das principais constatações feitas nesta análise remete às razões apontadas pelos deputados para explicar sua percepção do Plenário como a instância mais importante da Assembleia. Em parte, elas corroboram o que tem sido enfatizado pela literatura sobre a forma como as regras decisórias deslocam o processo decisório para o Plenário. A ausência, por exemplo, de regras que garantam às comissões influência nas etapas finais da decisão ou que lhes permitam antecipar-se ao Plenário, preservando a proposição de mudanças indesejadas, é parte da explicação para o predomínio do Plenário. Outras dimensões salientadas pelos deputados, no entanto, não têm recebido a devida atenção dos estudiosos.

Percebe-se, pelas razões assinaladas por grande parte dos legisladores, que é visto como positivo que o Plenário seja a instância mais importante da Casa. Para eles, esse fato é uma consequência natural de sua composição mais representativa, da característica de reunir todos ou a maioria dos membros da Casa e, dessa forma, congregar a pluralidade de visões e opiniões. Dada essa visão, não é surpresa que $73,6 \%$ dos deputados tenham afirmado, em outra questão do survey, que o Plenário deveria ser a instância mais importante da Assembleia. A Tabela 5 apresenta um cruzamento das respostas dadas às questões sobre qual é a instância mais importante da Casa e qual deveria ser a instância mais importante. Percebe-se que a maioria $(84,7 \%)$ dos deputados que assinalaram que o Plenário é a instância mais importante da Assembleia concordam que isso é desejável. Diferentemente, apenas uma minoria $(11,9 \%)$ dos que afirmaram que a Mesa Diretora é a instância mais importante da Casa, acham que ela deveria sê.lo. Entre os que afirmaram que as comissões permanentes são as instâncias mais importantes, pouco mais da metade acha que elas deveriam ser as mais importantes. 
OPINIÃO PÚBLICA, Campinas, vol. 18, n², novembro, 2012, p. 278-308

\section{Tabela 5}

Instância mais importante da Assembleia $\mathrm{x}$ instância que deveria ser a mais importante $(\%)^{18}$

\begin{tabular}{|c|c|c|c|c|}
\hline \multicolumn{5}{|c|}{ Instância que DEVERIA SER a mais importante } \\
\hline Instância mais importante & Mesa Diretora & $\begin{array}{c}\text { Comissões } \\
\text { Permanentes }\end{array}$ & Plenário & NS/NR \\
\hline Mesa Diretora & $\mathbf{1 1 , 9}$ & 15,6 & 70,4 & 2,2 \\
\hline Comissões Permanentes & 2,4 & $\mathbf{5 2 , 9}$ & 42,4 & 2,4 \\
\hline Plenário & 2,8 & 11,7 & $\mathbf{8 4 , 7}$ & 0,8 \\
\hline NS/NR & 0 & 27,3 & 72,7 & 0 \\
\hline Total & 5,1 & 19,9 & 73,6 & 1,5 \\
\hline
\end{tabular}

Fonte: Banco de Dados Pesquisa Trajetórias, perfis e padrões de interação de legisladores estaduais em doze unidades da federação - CEL-DCP.UFMG

As respostas dadas pelos parlamentares para justificar sua percepção de que o Plenário é a instância mais importante da Assembleia e a afirmação da grande maioria dos legisladores de que assim deveria ser podem ser interpretadas, numa chave próxima à do institucionalismo da escolha racional, como reflexo da aversão dos parlamentares às perdas de agenciamento resultantes da delegação. Há um consenso entre os estudiosos do Legislativo de que a delegação é indispensável no parlamento.

A delegação de poderes e funções sustenta-se na expectativa de que grupos menores, que contam com os recursos adequados, podem obter um melhor resultado, em menor tempo, no tocante à qualidade e/ou à estabilidade das decisões. Os ganhos advindos da delegação, geralmente, são definidos como maior capacidade de coordenação e decisão, superação de problemas de ação coletiva, obtenção de ganhos informacionais e redução da incerteza, além de maior agilidade (KIEWIET e MCCUBBINS, 1991). Por outro lado, todo ato de delegação implica em perdas de agenciamento, uma vez que, para desempenhar bem suas funções, os agentes precisam receber dos mandantes recursos de poder que podem abrir espaço para o comportamento oportunista dos primeiros (KIEWIET e MCCUBBINS, 1991; PRZEWORSKi, 1998; PereIRA, 2001; Llanos e Mustapic, 2005).

Em se tratando da delegação para as comissões, há o risco de que estas, como afirma Lemos (2006), venham a adquirir autonomia relevante com relação ao Plenário, constituindo-se em espaços nos quais uma minoria obtém benefícios desproporcionais com relação aos demais membros do Congresso. Sua menor visibilidade, segundo a autora, pode favorecer negociações com outros atores do Executivo ou provenientes de grupos de interesse "sem a transparência que deve prevalecer nos procedimentos democráticos" (LEMOS, 2006, p.157).

É certo que tais perdas podem ser parcialmente minimizadas com a introdução de mecanismos de controle, mas nunca podem ser completamente anuladas. Em contextos com alto nível de delegação como é o caso do Congresso norte-americano, no qual o processo decisório é altamente descentralizado nas comissões, os estudiosos tendem a concluir que, mesmo cientes dos riscos envolvidos, os legisladores optam por delegar, por acharem que ganharão mais do que perderão. A origem e a sobrevivência das regras de organização legislativa são explicadas em termos de eficácia, isto é, pelos ganhos que elas acarretam para aqueles que teriam poder para mudá-las.

18 Após se perguntar ao deputado por que ele considerava a instância X a mais importante, foi perguntado: "E, na opinião do(a) Sr(a), qual delas - Mesa Diretora, Comissões Permanentes ou Plenário - DEVERIA SER a mais importante?” 
ROCHA, M. M.; COSTA, A. Percepções dos deputados estaduais sobre o sistema...

Entretanto, essa visão não considera que determinadas regras podem continuar a subsistir mesmo se não correspondam aos interesses dos legisladores. Isso pode ocorrer, por exemplo, devido à incerteza dos deputados sobre os possíveis efeitos de sua modificação ou devido à falta de consenso ou poder político suficientes para alterá-las. As respostas da grande maioria dos deputados deixam claro que aqueles que acreditam que Mesa Diretora é a instância mais importante da Casa consideram seu poder excessivo e não estão satisfeitos com esse estado de coisas.

A mesma perspectiva pode iluminar a interpretação das respostas dos deputados relativas ao Plenário. É fato que grande parte dos legisladores justificou a importância desta instância a partir das regras do jogo legislativo que conduzem as decisões para o seu âmbito. Certamente, o temor das perdas de agenciamento envolvidas na delegação deve ser considerado para compreender porque a grande maioria dos parlamentares acha desejável que o Plenário seja o centro do processo de tomada de decisões. Como mostra Polsby (1968), a resistência em delegar para instâncias menores a responsabilidade pela decisão de questões importantes foi um dos fatores que impediu que, até meados do século XX, as comissões da House norte-americana tivessem um papel de relevo no processo legislativo.

Por outro lado, uma vez que parte significativa dos parlamentares recorreu a uma dimensão valorativa, suas respostas para explicar a predominância do Plenário enquanto instância decisória (somada ao aval da grande maioria a esse estado de coisas) também podem ser interpretadas, em parte, como refletindo suas visões e concepções sobre o Poder Legislativo. Visões estas que consagram os princípios da pluralidade, da representatividade e do poder da maioria. Como argumentam alguns autores, há outras razões, além da mera eficácia, que explicam a sobrevivência das instituições, como a incerteza que cerca a mudança institucional (TSEBELIS, 1998) e a força adquirida por determinadas regras ao longo do tempo, o que faz com que elas subsistam devido ao peso da tradição e à sua legitimidade aos olhos dos indivíduos (PUTNAM, 1996). Essas considerações ajudariam a explicar porque mesmo instituições que não são consideradas eficazes por indivíduos racionais continuam sendo mantidas por aqueles que possuem poder para modificá-las.

A análise das regras e das instituições formais é crucial para compreender a dinâmica política, uma vez que elas definem os jogadores, as jogadas permitidas e sua sequência, as penalidades e recompensas (TSEBELIS, 1998). Entretanto, essa análise, por si só, é insuficiente para explicar o comportamento político em toda a sua complexidade, assim como a origem e a permanência de certos arranjos institucionais. É importante lançar mão da dimensão relativa às percepções, atitudes e valores dos atores políticos que, em parte, são moldadas pelo seu contexto institucional, mas, também são forjadas em outros contextos, a partir de outras experiências. Essa afirmação reforça a importância de estudos sobre a trajetória e as percepções das elites políticas, como o que subsidiou essa análise.

\section{Considerações Finais}

O presente artigo discutiu o papel e o funcionamento das comissões parlamentares nos legislativos estaduais brasileiros. A estratégia de análise consistiu em confrontar as visões da literatura sobre o tema com as percepções dos deputados de 12 Assembleias Estaduais. Foi possível identificar 
OPINIÃO PÚBLICA, Campinas, vol. 18, n², novembro, 2012, p. 278-308

vários pontos de convergência, como a ênfase dada pela literatura e pelos deputados à centralização decisória em torno da Mesa Diretora e às regras que garantem ao Plenário afirmar-se como instância decisória central. De modo geral, as respostas dos parlamentares parecem confirmar a visão de que, no Brasil, as comissões parlamentares não desempenham o papel central que possuem nos legislativos norte-americanos. Entretanto, foram observadas importantes diferenças entre as explicações oferecidas pela literatura e as respostas dos parlamentares. Deve-se considerar também que a análise das percepções dos deputados sobre a importância da Mesa Diretora e do Plenário foi uma forma indireta de investigar porque as comissões estão impedidas de exercer um papel de relevo nas Assembleias Estaduais.

A escassez de estudos sobre as elites parlamentares no Brasil e em outras partes do mundo (DIÁz, 2009) remete obrigatoriamente a uma reflexão sobre os limites da técnica de survey e suas potencialidades e sobre como os dados produzidos no contexto da presente pesquisa podem contribuir para ampliar a compreensão sobre temas e problemas atinentes ao funcionamento do Poder Legislativo e à dinâmica política no nível estadual. Deve-se considerar que as respostas dadas pelos entrevistados não podem ser tomadas como reflexo perfeito da realidade, inclusive porque as entrevistas foram realizadas no ano de 2007 e início de 2008, portanto, nos dois primeiros anos do mandato dos legisladores (2007-2010).

Algumas considerações devem ser feitas para compreender o alcance e os limites deste artigo. A análise agregada dos dados não permite verificar o impacto de variáveis organizacionais sobre a percepção dos parlamentares e essa tarefa extrapolaria o escopo desse artigo. A análise dos dados desagregados por estado não se mostrou uma alternativa viável, seja devido à resultante redução do número de casos, seja pelo fato de que há bastante semelhança entre as Assembleias no que tange à distribuição de poderes entre Mesa Diretora, Plenário e Comissões. Um exemplo disso é o fato de que, com exceção dos estados de Mato Grosso e Minas Gerais, em todas as Assembleias, o Plenário foi considerado a instância decisória mais importante. Com exceção dos estados de Tocantins, Pernambuco e Minas Gerais, nos demais, a Mesa Diretora foi a segunda instância mais escolhida, seguida das comissões. Os casos que mais se desviam do padrão são, certamente, Minas Gerais e Mato Grosso: o primeiro por ser o único no qual o percentual de deputados que consideram as comissões as instâncias mais importantes é igual ao percentual dos que consideram o Plenário; e o segundo, pelo grande percentual de parlamentares que afirmou que a Mesa Diretora é a instância mais importante e pelo fato de nenhum deputado ter assinalado as comissões permanentes.

A análise das percepções dos parlamentares corroborou alguns aspectos enfatizados pela literatura e, ao mesmo tempo, permitiu problematizar outras dimensões como a importância da centralização decisória em torno do Poder Executivo e das lideranças partidárias como variáveis centrais para a explicação de porque o Plenário é uma instância tão crucial nos legislativos brasileiros. Seria necessária uma análise mais detida para discutir mais adequadamente algumas teses da literatura como a importância das comissões para os partidos majoritários e governistas ou seus potenciais para o exercício da fiscalização e para a atuação das oposições. Isso seria possível verificando o impacto de variáveis como o tamanho do partido e a posição em relação ao governo sobre as percepções dos parlamentares. Os objetivos restritos do artigo não permitiram chegar a esse nível de análise. Buscou-se 
ROCHA, M. M.; COSTA, A. Percepções dos deputados estaduais sobre o sistema...

aqui possibilitar uma primeira aproximação com as percepções dos parlamentares à luz do que afirmam os estudiosos do Poder Legislativo no Brasil.

\section{Referências Bibliográficas}

ABRÚCIO, F. Os Barões da Federação - os governadores e a redemocratização brasileira. São Paulo: DCP/USP.Hucitec, 1998.

AMORIM NETO, O. Of Presidents, parties, and ministers: cabinet formation and Legislative decision-making under separation of Powers. Dissertation. San Diego: University of California, 1998.

Amorim Neto, O.; SANTOS, F. M. A produção legislativa do Congresso: entre a paróquia e a nação. In: ViAnNA, L. W. (org.). A Democracia e os três poderes no Brasil. Belo Horizonte/Rio de Janeiro: UFMG/IUPERJ, 2002.

"The Inefficient Secret Revisited: The Legislative Input and Output of Brazilian Deputies". Legislative Studies Quarterly. Iowa City, lowa, EUA, vol. 28, n³, 2003.

ANASTASIA, M. F. J. Transformando o Legislativo: a experiência da Assembleia Legislativa de Minas Gerais. In: SANTOS, F. (org.). O Poder Legislativo nos Estados: diversidade e convergência. Rio de Janeiro: FGV Editora, 2001.

AnAstasia, F. e Melo, C.R. Accountability, Representação e Estabilidade Política no Brasil”. In: Abrucıo, F. E LouREIRo, M.R. (orgs.). O Estado numa era de reforma. Os anos FHC. Brasília, MP: SEGES, 2002.

AnASTASIA, M. F. J. e InÁCIO, M. "Democracia, Poder Legislativo, Interesses e Capacidades", Cadernos ASLEG/S, n’40, mai.ago 2010.

Arrow, K. Social choice and individual values. New Haven: Yale University Press, 1963.

BAHIA. Constituição do Estado da Bahia, promulgada em 05 de outubro de 1989, atualizada até a Emenda Constitucional $\mathrm{n}^{\circ} 12$, de 08 de novembro de 2006.

BAHIA. Resolução n 1.193 DE 17 de janeiro de 1985. Dispõe sobre o Regimento Interno da Assembleia Legislativa do Estado da Bahia (com modificações introduzidas até 1995).

CEARÁ. Constituição do Estado do Ceará, promulgada em 05 de outubro de 1989, atualizada até a Emenda Constitucional $n^{\circ} 56$ de 07 de janeiro de 2004.

CEARÁ. Resolução n 389, de 11 de dezembro de 1996. Institui o Regimento Interno da Assembleia Legislativa do Ceará. Atualizado até a Resolução n 550 , de 19.04.2007.

Centro de Estudos Legislativos (CEL-DCP.UfMG). Banco de Dados da Pesquisa Trajetórias, perfis e padrões de interação de legisladores estaduais em doze unidades da Federação.

Cox, G.W. and MccubBINS, M.D. Legislative Leviathan: Party Government in the House. Berkley and Los Angeles: University of California Press, 1993.

DIÁZ, A.M. Los estudios sobre elites parlamentarias. El caso latinoamericano. In: ANASTÁSIA, F.; DIAZ, A.M.; INÁCIO, M. e Rocha, M.M. (orgs.). Elites Parlamentares na América Latina. Belo Horizonte: Argvmentvm Editora, 2009.

DINIZ, s. "Interações entre os poderes executivo e legislativo no processo decisório: avaliando sucesso e fracasso presidencial". Dados, vol.48, n², 2005.

FIgUeIREDo, A. "Instituições e Política no Controle do Executivo". Dados: Revista de Ciências Sociais. vol. 44, n 4, p.689.727, 2001.

"Formação, Funcionamento e Desempenho das Coalizões de Governo no Brasil". $5^{\circ}$ Encontro ABCP.

Belo Horizonte, UFMG, 2007. 
OPINIÃO PÚBLICA, Campinas, vol. 18, n², novembro, 2012, p. 278-308

. Instituições Políticas e Governabilidade: desempenho do governo e apoio legislativo na democracia brasileira. In: MELO, C. R.; SÁEZ, M. A. (orgs.). A Democracia Brasileira: balanço e perspectivas para o século 21. Belo Horizonte: Editora UFMG, 2008.

FIgUeIREDo, A.C. e Limongl, F. Executivo e Legislativo na Nova Ordem Constitucional. São Paulo: Ed. Fundação Getúlio Vargas, 1999.

Gilligan, T.W. and KrehBiel, K. "Collective Decision-Making and Standing Committees: An Informational Rationale for Restrictive Amendment Procedures". Journal of Law, Economics and Organization, p.287-335, 1987.

GolÁs. Constituição do Estado do Goiás promulgada em 5 de outubro de 1989 com alterações até a Emenda Constitucional $n^{\circ} 33$, de 2 de janeiro de 2003.

GolÁs. Resolução n 1218, de 03 de julho de 2007. Institui o Regimento Interno da Assembleia Legislativa do Estado de Goiás.

Grohman, L.G.M. O processo legislativo no Rio Grande do Sul: 1995 a 1998. In: SANTOS, F. (org.). O poder legislativo nos estados: diversidade e convergência. 1 ed. Rio de Janeiro: Editora Fundação Getúlio Vargas, 2001.

InÁCIO, M. Estrutura e funcionamento na Câmara dos Deputados. In: Melo, C. R.; AlCÂNTARA SÁeZ, M. (orgs). A Democracia Brasileira: balanço e perspectivas para o século 21. Belo Horizonte: Editora UFMG, 2007.

KIEWIET, R.and MccubbINS, M.D. The Logic of Delegation. Chicago: University of Chicago Press, 1991.

KREHBIEL, K. Information and legislative organization. Ann Arbor: University of Michigan Press, 1991.

LEMOS, L.B. "El Sistema de Comisiones en el Senado Brasileño: jieraquía y concentración de poderes en la década de 1990”. America Latina Hoy, 43, p. 155-182. Ediciones universidad de Salamanca, 2006.

LIMONGI, F. "O Novo Institucionalismo e Os Estudos Legislativos: A Literatura Norte-Americana Recente". BIB. Boletim Informativo Bibliográfico, 37, p.3.38, 1994.

Llanos, M. e Mustapic, A.M. (orgs.). Controle parlamentar na Alemanha, na Argentina e no Brasil. Rio de Janeiro: Fundação Konrad Adenauer, 2005.

Mato Grosso. Constituição do Estado do Mato Grosso, promulgada em 5 de outubro de 1989. Atualizada até a Emenda Constitucional $n^{\circ} 51$ de 28/02/2007.

MATO GRosso. Resolução n 677, de 20 de dezembro de 2006. Aprova o Regimento Interno da Assembleia Legislativa do Estado de Mato Grosso.

MINAS GeRAIS. Constituição do Estado de Minas Gerais promulgada em 5 de outubro de 1989, atualizada até a Emenda Constitucional nos 1 a 81 de 9 de julho de 2009.

Minas GeRaIS. Resolução n 5.176, de 1997 com alterações até a Resolução nº 5.322, de 2008. Institui o Regimento Interno da Assembleia Legislativa de Minas Gerais.

Montero, M.G. e LoPEZ, F.S. "Las comisiones legislativas en América Latina: una clasificación institucional y empírica". Working Papers, 212, Institut de Ciències Polítiques i Socials. Barcelona, 2002.

NASCIMENTO, E.O. "As fundações institucionais do sistema de comissões brasileiro". Trabalho apresentado no III Seminário de Ciência Política da UFPE, Recife. Mimeo, 2007.

PARÁ. Constituição do Estado do Pará promulgada em promulgada em 5 de outubro de 1989, atualizada até a edição da Emenda Constitucional n 36, de 24 de fevereiro de 2007.

PARÁ. Resolução nº 02/94. Institui o Regimento Interno da Assembleia Legislativa do Estado do Pará.

PereIRA, A.R. Sob a ótica da delegação: governadores e Assembleia no Brasil pós-1988. In: SANToS, F. (org.). O Poder Legislativo nos Estados: divergência e convergência. Rio de Janeiro: FGV Editora, 2001.

Pereira, C. e Muller, B. "Uma teoria da preponderância do Poder Executivo: o sistema de comissões no Legislativo brasileiro". Revista Brasileira de Ciências Sociais, vol.15, n 43, p.45-67, 2000.

Pernambuco. Constituição do Estado de Pernambuco promulgada em 5 de outubro de 1989, atualizada até a Emenda Constitucional $\mathrm{n}^{\circ} 32$, de 18 de dezembro de 2008. 
ROCHA, M. M.; COSTA, A. Percepções dos deputados estaduais sobre o sistema...

Pernambuco. Resolução n 905. Altera o Regimento Interno da Assembleia Legislativa de Pernambuco de 22 de dezembro de 2008.

PoLSBY, N. "The Institutionalization of the U.S. House of Representatives". American Political Science Review, 62, p.14468, 1968.

PrzeWorski, A. O Estado e o Cidadão. Mimeografado, 1998.

PutNAm, R.D.; LeONARDI, R.; NANETTI, R. Comunidade e democracia: a experiência da Itália moderna. Rio de Janeiro: FGV, 1996.

Pribeiral, T. "Comissão de Constituição e Justiça: Uma ilha de Institucionalização no Congresso Nacional". Revista do Legislativo da ALMG, 24, p.66.82, 1998,

RICCI, P. e LEMOS, L.B. Produção legislativa e preferências eleitorais na Comissão de Agricultura e Política Rural da Câmara dos Deputados. Revista Brasileira de Ciências Sociais. São Paulo, vol. 19, n 55, 2004.

RIO DE JANEIRO. Constituição do Estado do Rio de Janeiro promulgada em 5 de outubro de 1989, atualizada até a Emenda Constitucional $n^{\circ} 41$, de 14.04.09.

RIO DE JANEIRO. Resolução n 810 de 1997. Dispõe sobre o Regimento Interno da Assembleia Legislativa do Rio de Janeiro.

Rio Grande Do Sul. Constituição do Estado do Rio Grande do Sul promulgada em 3 de outubro de 1989. Com as alterações adotadas pelas Emendas Constitucionais de $n^{\circ}$ 1, de 1991, a 57, de 2008.

RIo GRANDE Do Sul. Resolução n 2.288, de 18 de janeiro de 1991. Institui o Regimento Interno da Assembleia Legislativa de São Paulo. Com alterações até dezembro de 2008.

Rosenthal, A. "Legislative behavior and legislative oversight". Legislative Studies Quarterly, vol. VI, n 1, p.115·131, 1981.

Santa CatARINA. Constituição do Estado de Santa Catarina promulgada em 05 de outubro de 1989 com modificações até a emenda Constitucional $n^{\circ} 047$ de 18 de janeiro de 2008.

SAnta Catarina. Regimento Interno da Assembleia de Santa Catarina com alterações até a Resolução no 1 de 2009.

Santos, F. e Almeida, A. "Teoria Informacional e a Seleção de Relatores na Câmara dos Deputados". Dados: Revista de Ciências Sociais. Rio de Janeiro, Vol. 48, n 4, p. 693.735, 2005.

"Urgency Petitions and the Informational Problem in the Brazilian Chamber of Deputies". Mimeo, 2008.

SAntos, F. (org.). O Poder Legislativo nos Estados: divergência e convergência. Rio de Janeiro: FGV Editora, 2001,

. Governos de Coalizão no Sistema Presidencial: o caso do Brasil sob a égide da Constituição de 1988. In: AvritZer, L.; ANASTÁsIA, F. (orgs.). Reforma Política no Brasil. Belo Horizonte: Editora UFMG, 2006.

O Poder Legislativo no Presidencialismo de Coalizão. Belo Horizonte: Editora UFMG, 2003.

SÃo PAULO. Constituição do Estado de São Paulo promulgada em 5 de outubro de 1989, com as alterações adotadas pelas Emendas Constitucionais $n^{\circ}$ s 1/1990 a 31/2009.

SÃo PAULO. Resolução 576, de 26 de junho de 1970. Institui o Regimento Interno da Assembleia Legislativa de São Paulo. Atualizada até a Resolução 852, de 17 de outubro de 2007.

Shepsle, K. and WeInGASt, B. "Institutional foundations of committee power". American Political Science Review, n. 81, p. $85 \cdot 104,1987$.

Souza, C. e Dantas Neto, P.F. Governo, políticas públicas e elites políticas nos estados brasileiros. Rio de Janeiro: Revan, 2006.

STROM, K. Delegation and accountability in parliamentary democracies. In: Rethinking the democracy in the new millennium. University of Houston, 2000.

TocANTINS. Constituição do Estado do Tocantins promulgada em 5 de outubro de 1989 com as alterações adotadas pelas Emendas Constitucionais nos 01/89 a 19/2006. 
ToCANTIns. Resolução n² 201, de 18/9/1997. Institui o Regimento Interno da Assembleia Legislativa do Tocantins. Atualizada até a Resolução n. 267, de 8/07/2008.

Tomı, F.R.L. Medidas provisória, iniciativas e decisões legislativas no processo decisório estadual catarinense. In: CARreirão, Y. Borba, J. (orgs.). Os partidos na política catarinense - eleições, processo legislativo, políticas públicas. Florianópolis, Insular, 2006,

Tomio, F.R.L. e CANTo, E.R. "Medidas provisórias no processo decisório estadual". Apresentado no $4^{\circ}$ Encontro da Associação Brasileira de Ciência Política, 2004.

Tomı, F.R.L e RICCI, P. “Conexão eleitoral, processo legislativo e estratégias parlamentares nas Assembleias Legislativas Estaduais". Apresentado no $6^{\circ}$ Encontro da Associação Brasileira de Ciência Política, 2008.

TSEBELIS, G. Jogos ocultos: escolha racional no campo da política comparada. São Paulo: Edusp, 1998.

WEINGAST, B.R. and MARSHAL, W.J. "The industrial organization of Congress: or, why legislatures, like firms, are not organized as markets". Journal of Political Economy, n. 96 (1), p. 133.63, 1988.

Marta Mendes da Rocha·mendes_rocha@yahoo.com.br

Alessandra Costa·arc.costa@ig.com.br

Submetido à publicação em janeiro de 2011.

Versão final aprovada em novembro de 2011. 